\title{
Angiotensin-converting enzyme overexpression in myelomonocytes prevents Alzheimer's-like cognitive decline
}

\author{
Kenneth E. Bernstein, ${ }^{1,2}$ Yosef Koronyo, ${ }^{3}$ Brenda C. Salumbides, ${ }^{3}$ \\ Julia Sheyn, ${ }^{3}$ Lindsey Pelissier, ${ }^{3}$ Dahabada H.J. Lopes, ${ }^{3}$ Kandarp H. Shah, ${ }^{1}$ \\ Ellen A. Bernstein, ${ }^{1}$ Dieu-Trang Fuchs, ${ }^{3}$ Jeff J.-Y. Yu, ${ }^{3}$ Michael Pham, ${ }^{3}$ Keith L. Black, ${ }^{3}$ \\ Xiao Z. Shen,1,2 Sebastien Fuchs, 1,2,4 and Maya Koronyo-Hamaoui 1,3 \\ 1Department of Biomedical Sciences, ${ }^{2}$ Department of Pathology and Laboratory Medicine, and \\ ${ }^{3}$ Department of Neurosurgery and the Maxine Dunitz Neurosurgical Research Institute, Cedars-Sinai Medical Center, Los Angeles, California, USA \\ ${ }^{4}$ Department of Basic Medical Sciences, College of Osteopathic Medicine, Western University of Health Sciences, Pomona, California, USA
}

\begin{abstract}
Cognitive decline in patients with Alzheimer's disease (AD) is associated with elevated brain levels of amyloid $\beta$ protein $(A \beta)$, particularly neurotoxic $A \beta_{1-42}$. Angiotensin-converting enzyme (ACE) can degrade $A \beta_{1-42}$, and ACE overexpression in myelomonocytic cells enhances their immune function. To examine the effect of targeted ACE overexpression on $A D$, we crossed $A C E^{10 / 10}$ mice, which overexpress $A C E$ in myelomonocytes using the $c$-fms promoter, with the transgenic $A P P_{S W E} / P S 1_{\triangle E 9}$ mouse model of $\mathrm{AD}\left(\mathrm{AD}^{+}\right)$. Evaluation of brain tissue from these $\mathrm{AD}^{+} \mathrm{ACE}{ }^{10 / 10}$ mice at 7 and 13 months revealed that levels of both soluble and insoluble brain $\mathrm{A} \beta_{1-42}$ were reduced compared with those in $\mathrm{AD}^{+}$mice. Furthermore, both plaque burden and astrogliosis were drastically reduced. Administration of the $A C E$ inhibitor ramipril increased $A \beta$ levels in $A^{+} A C E^{10 / 10}$ mice compared with the levels induced by the $\mathrm{ACE}$-independent vasodilator hydralazine. Overall, $\mathrm{AD}^{+} \mathrm{ACE}^{10 / 10}$ mice had less brain-infiltrating cells, consistent with reduced $\mathrm{AD}$-associated pathology, though ACE-overexpressing macrophages were abundant around and engulfing $A \beta$ plaques. At 11 and 12 months of age, the $\mathrm{AD}^{+} A C E^{10 / W T}$ and $\mathrm{AD}^{+} \mathrm{ACE}^{10 / 10}$ mice were virtually equivalent to non-AD mice in cognitive ability, as assessed by maze-based behavioral tests. Our data demonstrate that an enhanced immune response, coupled with increased myelomonocytic expression of catalytically active ACE, prevents cognitive decline in a murine model of AD.
\end{abstract}

\section{Introduction}

Alzheimer's disease (AD) is the most common cause of dementia in the elderly and is characterized by a progressive deterioration of cognitive and behavioral functions. Indeed, throughout the world, the incidence of $\mathrm{AD}$ is rising as the population ages; it is estimated that over 5 million Americans and well above 35 million people worldwide are currently living with $\mathrm{AD}(1)$. AD pathogenesis is intimately associated with elevated brain levels of amyloid $\beta$ protein (A $\beta$ ) in both soluble and extracellular aggregated forms (A $\beta$ plaques) $(2,3)$. A $\beta$ alloforms are most commonly found as peptides of 38 to 43 amino acids, with $A \beta_{1-42}$ being most closely associated with AD pathology (4-6). These peptides are the cleavage products of the transmembrane amyloid precursor protein (APP) and are naturally produced within the CNS throughout life. Cerebral $\mathrm{A} \beta$ accumulation and aggregation are thought to be one of the main causes of the neuronal loss and cognitive decline seen in $\mathrm{AD}$ (7). In addition, persistent neuroinflammation, consisting of reactive astrocytes and activated microglia that become cytotoxic in response to chronically elevated amyloidogenic $A \beta$, is thought to contribute to disease progression (8-11).

It is still unclear whether abnormalities leading to increased production of $A \beta$ or deficits in its clearance are the primary culprits responsible for cerebral $\mathrm{A} \beta$ accumulation in nonfamilial $\mathrm{AD}$

Authorship note: Kenneth E. Bernstein and Yosef Koronyo contributed equally to this work.

Conflict of interest: The authors have declared that no conflict of interest exists. Citation for this article: J Clin Invest. 2014;124(3):1000-1012. doi:10.1172/JCI66541.
(12-14). A recent clinical study suggests that the common sporadic cases are associated with insufficient $A \beta$ clearance rather than increased production (15). While there can be poor correlation between the amount of $A \beta$ plaque deposition and cognitive deterioration, a common view is that any strategy that reduces $A \beta$, particularly soluble and small oligomeric forms of $A \beta_{1-42}$, will be advantageous in preventing $\mathrm{AD}$ progression $(7,16-18)$. $\mathrm{A} \beta$ removal is regulated by multiple mechanisms, including its degradation by several peptidases and phagocytosis by innate immune cells.

Angiotensin-converting enzyme (ACE) is a carboxy dipeptidase that is best known for the conversion of angiotensin I into the vasoconstrictor angiotensin II (19). However, ACE is a fairly nonspecific peptidase that has been shown to hydrolyze peptides as small as three amino acids and as large as $A \beta_{1-42}(20-22)$. While large amounts of ACE are made by vascular endothelium, virtually every tissue makes some ACE (23). Because of this and because of the substrate promiscuity of the enzyme, ACE participates in many physiologic processes, though its precise role in clearing $A \beta$ is not well understood.

We previously created a mouse model termed $\mathrm{ACE}^{10 / 10}$, in which gene targeting was used to inactivate the intrinsic Ace promoter and place Ace expression under the control of the $c$-fms promoter (24). As a result, ACE was overexpressed in myelomonocytic lineage cells (monocytes, macrophages, microglia, etc.), depending on the degree to which cells normally produce C-FMS. Homozygous ACE ${ }^{10 / 10}$ mice lack ACE expression by ECs and other tissues that do not recognize the $c$-fms promoter, while heterozygous $\mathrm{ACE}^{10 / \mathrm{WT}}$ mice do maintain some endogenous ACE expression. 
Using these mouse models, we demonstrated that ACE can also affect immune function (24-26). Specifically, ACE ${ }^{10 / 10}$ mice had an increased immune response and decreased disease after challenge with tumors (24) or bacterial infections (25). This was due to the enhanced immune reactivity of ACE-overexpressing macrophages. The phenotype is transferable by BM transplantation and is directly attributable to ACE catalytic activity.

Numerous studies have suggested that the development of cerebral $A \beta$ plaques elicits both a resident microglial and a blood-borne monocytic response (27-35). Further, we found that following immunization, increased peripheral monocyte-derived macrophages homed to $\mathrm{A} \beta$ plaques and facilitated their clearance $(31,36)$. These and other studies suggest that BM-derived macrophages are more efficient than microglia in restricting $A \beta$ plaques in mouse models of $\mathrm{AD}(29-31,34,36-41)$. Once recruited to the brain, such cells appear to attenuate neuropathology and improve cognitive function.

$\mathrm{ACE}^{10 / 10}$ mice have two features that we hypothesized might contribute to reducing the progression of AD. Their macrophages have a markedly enhanced immune response, achieved by overexpression of ACE, an enzyme directly capable of cleaving $A \beta_{1-42}$ into less pathogenic peptides. Thus, we wondered whether the local delivery of an $A \beta$-cleaving enzyme by inflammatory cells would prove effective at reducing $\mathrm{AD}$ progression. Here, we report that the crossing of $\mathrm{ACE}^{10 / 10}$ mice with a mouse model of $\mathrm{AD}$ results in a marked reduction in AD-like pathology and symptoms. Not only did these mice show a substantial decrease in levels of soluble and insoluble $A \beta$ and diminished astrocytosis, but also a maze-based assessment of cognitive function showed behavior very similar to that of the control non-AD mice. Thus, an approach designed to enhance the peripheral immune response, coupled with increased inflammatory cell expression of an enzyme capable of cleaving $A \beta$ (ACE), resulted in an essentially complete prevention of the cognitive decline observed in a model of AD.

\section{Results}

Reduced plaque burden. To study $\mathrm{AD}$ in $\mathrm{ACE}^{10 / 10}$ mice, these animals were crossed with double-Tg $\mathrm{APP}_{\mathrm{SWE}} / \mathrm{PS} 1_{\triangle \mathrm{E} 9}(\mathrm{ADtg})$ mice. This is a well-established mouse model for $\mathrm{AD}$, in which animals overproduce human $\mathrm{A} \beta$ peptides, develop plaques with age, and show progressive memory and learning deficits mimicking some aspects of human $\mathrm{AD}$ (42). The mouse cross-breading eventually yielded $\operatorname{ADtg}\left(\mathrm{AD}^{+}\right)$mice with WT ACE $\left(\mathrm{AD}^{+} \mathrm{ACE}{ }^{\mathrm{WT} / \mathrm{WT}}\right)$ mice heterozygous for the ACE 10 allele $\left(\mathrm{AD}^{+} \mathrm{ACE}{ }^{10 / \mathrm{WT}}\right)$ and mice homozygous for this allele $\left(\mathrm{AD}^{+} \mathrm{ACE}{ }^{10 / 10}\right)$, as well as mice lacking the $\mathrm{AD}$ Tgs and WT for ACE $\left(\mathrm{AD}^{-} \mathrm{ACE}{ }^{\mathrm{WT} / \mathrm{WT}}\right)$. All mice were on a C57BL/ 6 background, and the ACE 10 alleles had no effect on blood pressure (Supplemental Figure 1; supplemental material available online with this article; doi:10.1172/JCI66541DS1), similar to what was previously reported (24). Assessment of cerebral APP levels (43) showed no differences in the expression of APP among the different ACE genotypes (Supplemental Figure 2). At 3 months of age, brain $\mathrm{A} \beta$ levels were equivalent in $\mathrm{AD}^{+} \mathrm{ACE}^{10 / 10}$ and $\mathrm{AD}^{+} \mathrm{ACE}$ WT/WT mice (Supplemental Figure 3).

An initial evaluation of plaque burden was qualitatively assessed in coronal brain sections from $\mathrm{AD}^{+} \mathrm{ACE}^{\mathrm{WT} / \mathrm{WT}}$ and age- and gender-matched $\mathrm{AD}^{+} \mathrm{ACE}{ }^{10 / 10}$ mice that were 255 days ( 8.5 months) old. Paraffin sections were immunolabeled with antihuman $A \beta$ $\mathrm{mAb} 6 \mathrm{~F} / 3 \mathrm{D}$. This showed a marked reduction of cortical and hippocampal $\mathrm{A} \beta$ burden in $\mathrm{AD}^{+} \mathrm{ACE}^{10 / 10}$ mice as compared with that in $\mathrm{AD}^{+} \mathrm{ACE}{ }^{\mathrm{WT} / \mathrm{WT}}$ mice (Figure $1 \mathrm{~A}$ ).
To precisely quantitate $A \beta$ plaque pathology, cohorts of 7 - to 8-month-old mice were studied, the age at which ADtg mice start to develop cognitive deficits and exhibit substantial neuropathology (44). To measure cerebral A $\beta$ burden, serial coronal brain sections were immunolabeled with antihuman $A \beta \mathrm{mAb}$ 6E10. Sections were colabeled with thioflavine-S (Thio-S), which binds to fibrillary $A \beta$ aggregates that are typical of mature plaques. Representative histologic sections showed a substantial reduction in $6 \mathrm{E} 10^{+}$and $\mathrm{Thio}^{-} \mathrm{S}^{+} \mathrm{A} \beta$ plaque burden in both $\mathrm{AD}^{+} \mathrm{ACE}^{10 / 10}$ and $\mathrm{AD}^{+} \mathrm{ACE}^{10 / W T}$ mice as compared with that seen in $\mathrm{AD}^{+} \mathrm{ACE}{ }^{\mathrm{WT} / \mathrm{WT}}$ mice (Figure $1 \mathrm{~B}$ ). Quantitation of cortical and hippocampal plaque areas indicated a significant reduction in both $6 \mathrm{E} 10^{+}$and Thio-S ${ }^{+}$plaque load in ADtg mice bearing the ACE 10 allele(s) (Figure 1, C and D). Plaque area was reduced by $31 \%$ and $56 \%$, respectively, in mice with a single ACE 10 allele $\left(\mathrm{AD}^{+} \mathrm{ACE}{ }^{10 / W T}\right)$ versus $\mathrm{AD}^{+} \mathrm{ACE}^{\mathrm{WT} / \mathrm{WT}}$ mice. A greater reduction in plaque area was observed in $\mathrm{AD}^{+} \mathrm{ACE}^{10 / 10}$ mice, which showed a reduced plaque burden of $69 \%$ to $79 \%$ compared with $\mathrm{AD}^{+} \mathrm{ACE}^{\mathrm{WT} / \mathrm{WT}}$ mice $(P<0.0001)$.

We also assessed brain-insoluble $A \beta_{1-42}$ levels by quantitative ELISA analysis (Supplemental Figure 4). We found that 7-monthold $\mathrm{AD}^{+} \mathrm{ACE}^{10 / \mathrm{WT}}$ and $\mathrm{AD}^{+} \mathrm{ACE}{ }^{10 / 10}$ mice had a respective average of $33 \%$ and $64 \%$ less insoluble $A \beta_{1-42}$ compared with $\mathrm{AD}^{+} \mathrm{ACE} \mathrm{ET}^{\mathrm{WT}} / \mathrm{WT}$ mice. At 13 months of age, $\mathrm{AD}^{+} \mathrm{ACE}^{10 / 10}$ mice averaged $30 \%$ less insoluble $\mathrm{A} \beta_{1-42}$ as compared with $\mathrm{AD}^{+} \mathrm{ACE} \mathrm{ET}^{\mathrm{WT} / \mathrm{WT}}$ mice. These data substantiate our immunohistochemical analysis.

Analysis of ACE levels in the brain confirmed the expected ACE level increase in $\mathrm{AD}^{+} \mathrm{ACE}{ }^{10 / \mathrm{WT}}$ and $\mathrm{AD}^{+} \mathrm{ACE}^{10 / 10}$ mice (Supplemental Figure 5). While there appeared to be an inverse relationship between parenchymal $A \beta$ plaque burden and ACE levels in the brain, differences between $\mathrm{AD}^{+} \mathrm{ACE}^{10 / \mathrm{WT}}$ and $\mathrm{AD}^{+} \mathrm{ACE}^{10 / 10}$ mice reached significance only in the Thio-S analysis of cortical and hippocampal plaque areas (Figure 1D).

Perivascular $A \beta$ deposition. Deposition of $A \beta$ in the wall of blood vessels has been associated with neuroinflammation and dementia (45). Vascular $A \beta$ was first investigated in $A \beta$-stained paraffin brain sections from 8.5 -month-old $\mathrm{AD}^{+} \mathrm{ACE} \mathrm{E}^{10 / 10}$ and age- and gender-matched $\mathrm{AD}^{+} \mathrm{ACE}{ }^{\mathrm{WT} / \mathrm{WT}}$ mice (Figure $2 \mathrm{~A}$ ). While the $\mathrm{AD}^{+} \mathrm{ACE}{ }^{10 / 10}$ mice had substantially less overall parenchymal $A \beta$, they presented with perivascular deposition of $A \beta$. To more completely characterize vascular A $\beta$, PFA-fixed hippocampal sections of 7- to 8-month-old $\mathrm{AD}^{+} \mathrm{ACE}^{\mathrm{WT} / \mathrm{WT}}, \mathrm{AD}^{+} \mathrm{ACE}{ }^{10 / \mathrm{WT}}$, and $\mathrm{AD}^{+} \mathrm{ACE}{ }^{10 / 10}$ mice were stained with Thio-S, anti-CD31 (an endothelial marker), and 6E10. Here, serial sections were studied by fluorescence microscopy, and perivascular $A \beta$ was quantified by Thio-S ${ }^{+}$area (Figure 2, B and C). Separate histologic sections were stained for anti-CD31 and 6E10 (antihuman A $\beta$ ), and perivascular $\mathrm{A} \beta$ was quantified by $6 \mathrm{E} 10^{+}$area (Supplemental Figure 6). Both studies produced the same result; whether assessed by Thio-S staining or by staining with an anti-A $\beta$ antibody, $\mathrm{AD}^{+} \mathrm{ACE}^{10 / \mathrm{WT}}$ mice had substantially less perivascular $\mathrm{A} \beta$ than either $\mathrm{AD}^{+} \mathrm{ACE} \mathrm{WT}^{\mathrm{WT} / \mathrm{WT}}$ or $\mathrm{AD}^{+} \mathrm{ACE}^{10 / 10}$ mice (Figure $2 \mathrm{C}$, $P$ values $<0.0001)$. In contrast, there was no significant difference in the amount of perivascular $\mathrm{A} \beta$ between $\mathrm{AD}^{+} \mathrm{ACE}$ WT/WT and $\mathrm{AD}^{+} \mathrm{ACE} \mathrm{E}^{10 / 10}$ mice. One of the major differences between $\mathrm{AD}^{+} \mathrm{ACE}{ }^{10 / W T}$ and $\mathrm{AD}^{+} \mathrm{ACE}^{10 / 10}$ mice is that $\mathrm{AD}^{+} \mathrm{ACE}^{10 / 10}$ mice lack ACE expression in vascular endothelium.

Reduced astrogliosis. Astrocytes are the main type of glial cells in the brain. Associated with AD progression, astrocytes migrate to $\mathrm{A} \beta$ plaques and exhibit increased reactivity and cytotoxicity (termed 
A

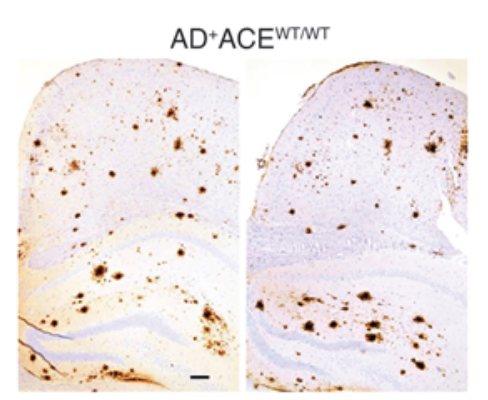

$A D^{+} A_{C E}^{10 / 10}$

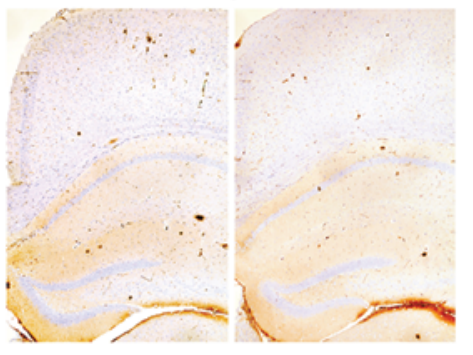

B

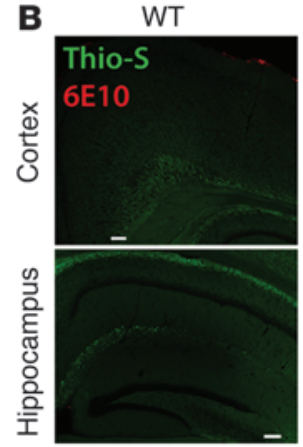

$A D^{+} A C E^{10 N T}$

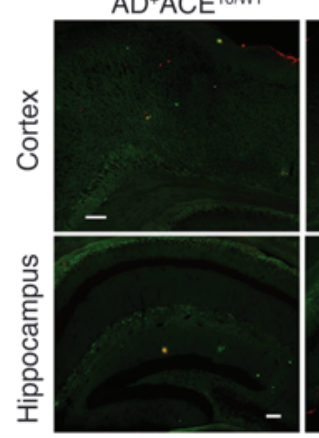

$\mathrm{AD}^{+} \mathrm{ACE}{ }^{\mathrm{WT}} \mathrm{NT}$

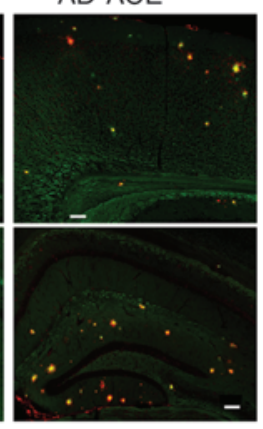

$\mathrm{AD}^{+} \mathrm{ACE} \mathrm{E}^{10 / 10}$

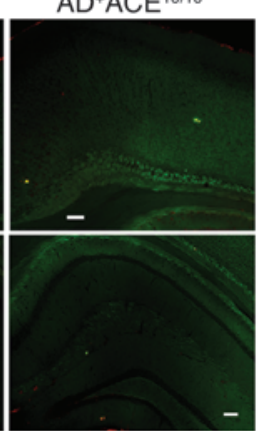

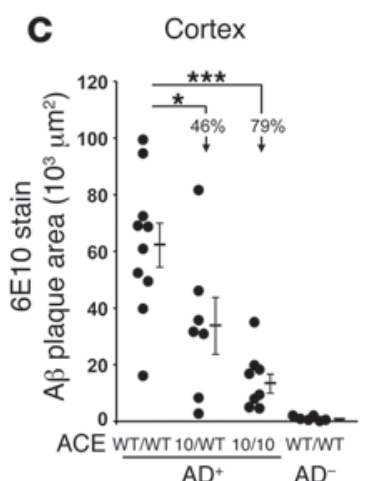

Hippocampus
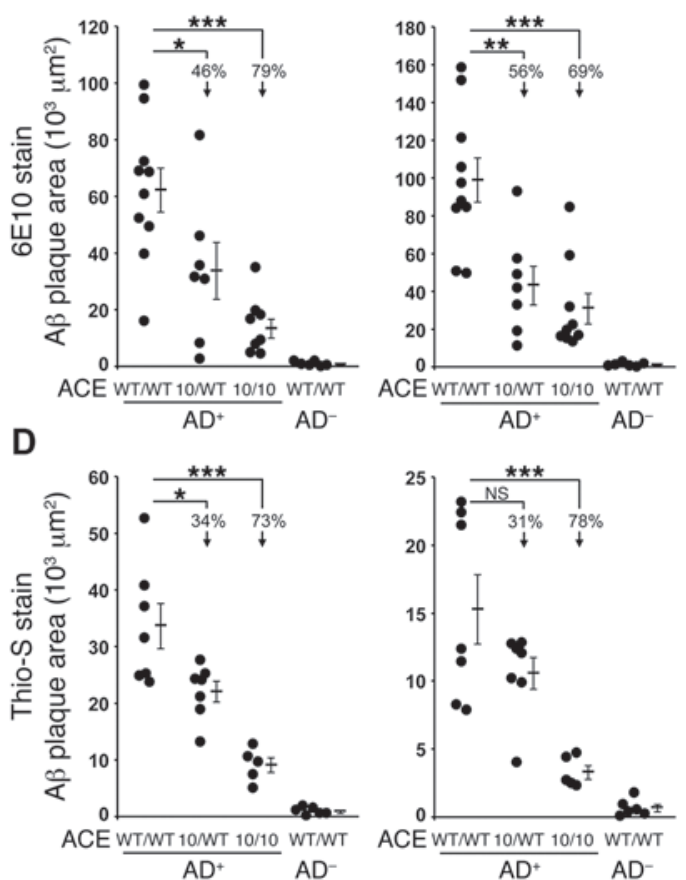

WT/WT

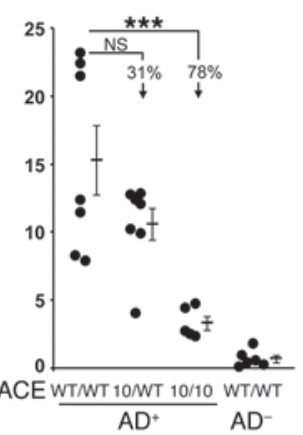

\section{Figure 1}

Targeted ACE overexpression in myelomonocytic cells is associated with reduced A $\beta$ plaque burden. (A) Micrographs of paraffin sections from $A D^{+} A C E^{W T / N T}$ and $A D^{+} A C E^{10 / 10}$ brains labeled for human $A \beta$ using the $\mathrm{mAb} 6 \mathrm{~F} / 3 \mathrm{D}$ and standard immunohistochemical techniques. All mice were 255 days ( 8.5 months) old. $A D^{+}$mice that were WT for $A C E$ showed large numbers of $A \beta$ plaques in both the cingulate cortex and the hippocampus. In contrast, $A D^{+}$mice that were $A C E^{10 / 10}$ demonstrated a very marked reduction in the number of $A \beta$ plaques. $n=4$ per group. (B) Paraformaldehyde-fixed brain sections from 7- to 8-month-old mice were colabeled with the anti-human A $\beta$ mAb 6E10 (red) and Thio-S (green), which binds to fibrillar $A \beta$. Scale bars: $100 \mu \mathrm{m}$. Sections were studied by immunofluorescence (B) and quantitatively assessed for $A \beta$ plaque area in the cortex and hippocampus (C and D). Data for individual mice as well as for group means and SEM are indicated. Percentages of the reduction in mean plaque area in $\mathrm{AD}^{+}$mice heterozygous or homozygous for the ACE 10 allele compared with mice WT for ACE are indicated. The presence of one or two $A C E 10$ alleles substantially reduced the plaque area. $A D^{+} A C E^{10 / 10}$ mice had fewer plaques than did $A D^{+} A C E^{10 / W T}$ mice, but this only reached a significance of $P<0.05$ (D, left and right panels) and is not indicated. $n=7-10$ mice for 6 E10 staining and $5-7$ mice for Thio-S staining. ${ }^{*} P<0.05 ;{ }^{* \star} P<0.001 ;{ }^{* *} P<0.0001$.

astrogliosis or astrocytosis) $(11,46,47)$. These astrocytes also increase expression of the astrocyte-specific glial fibrillary acidic protein (GFAP). To evaluate astrogliosis, coronal sections from 7- to 8-month-old mice were stained with an anti-GFAP antibody and assessed for both the number of positive cells and the immunoreactive area. Representative histologic sections are shown in Figure 3A, while quantitative analysis is presented in Figure 3B. These data showed a very significant reduction $(45 \%-57 \%)$ in both cell numbers and area of astrogliosis in $\mathrm{AD}^{+}$mice that were either heterozygous or homozygous for the ACE 10 allele (Figure 3B; $P$ values $<0.001$ ). In fact, $\mathrm{AD}^{+} \mathrm{ACE}{ }^{10 / \mathrm{WT}}$ and $\mathrm{AD}^{+} \mathrm{ACE}^{10 / 10}$ were not significantly different from age-matched non-Tg control mice $\left(\mathrm{AD}^{-} \mathrm{ACE}^{\mathrm{WT}} \mathrm{T} / \mathrm{WT}\right)$.

We also examined astrogliosis in a cohort of 13-month-old mice (Figure 3C). Even at this stage of disease, both the area of astrogliosis and the number of $\mathrm{GFAP}^{+}$cells were reduced by $50 \%$ in $\mathrm{AD}^{+} \mathrm{ACE}^{10 / 10}$ mice as compared with those in $\mathrm{AD}^{+} \mathrm{ACE}^{\mathrm{WT} / \mathrm{WT}}$ mice. Thus, the analysis of $\mathrm{GFAP}^{+}$cells at both 7 and 13 months showed a consistent reduction in astrocytosis in $\mathrm{AD}^{+}$mice overexpressing ACE in myelomonocytic cells.

Reduced soluble brain $A \beta_{1-42}$ and $A \beta_{1-40}$. Soluble $A \beta_{1-42}$ peptide is thought to be particularly neurotoxic, and elevated cerebral levels of this peptide have been associated with cognitive def- icits in $\mathrm{AD}(5,7)$. We measured soluble human $\mathrm{A} \beta_{1-42}$ in the brains of $\mathrm{AD}^{+}$mice at 5, 7, and 13 months of age (Figure 4, $A-C)$. At 5 months of age, we observed relatively low levels of $\mathrm{A} \beta_{1-42}$ in all groups. However, even at this point, $\mathrm{AD}^{+} \mathrm{ACE}^{10 / 10}$ mice had a $45 \%$ reduction in soluble $A \beta_{1-42}$. By 7 months of age, the trend was clearer, with the $\mathrm{AD}^{+} \mathrm{ACE}^{10 / \mathrm{WT}}$ and $\mathrm{AD}^{+} \mathrm{ACE}^{10 / 10}$ mice having $38 \%$ and $44 \%$ reductions, respectively, in soluble $A \beta_{1-42}$ levels as compared with those in ADtg mice WT for $\mathrm{ACE}\left(\mathrm{AD}^{+} \mathrm{ACE} \mathrm{WT}^{\mathrm{WT}}\right)$. These differences are highly statistically significant $(P<0.001)$. By 13 months of age, the percentage difference between the $\mathrm{AD}^{+} \mathrm{ACE}^{\mathrm{WT} / \mathrm{WT}}$ and $\mathrm{AD}^{+} \mathrm{ACE}^{10 / 10}$ mice had contracted (15\%), though it remained significant $(P<0.05)$. At this age, the nature of the aggressive genetic model of $\mathrm{AD}$ is such that there is abundant soluble $\mathrm{A} \beta_{1-42}$ that swamps the ability of both groups of animals to clear the peptide. However, the absolute reduction in soluble $A \beta_{1-42}$ concentrations (i.e., the difference of the means) between $\mathrm{AD}^{+} \mathrm{ACE}^{\mathrm{WT} / \mathrm{WT}}$ and $\mathrm{AD}^{+} \mathrm{ACE}^{10 / 10}$ mice at 5,7 , and 13 months of age is 23,109 , and $324 \mathrm{pg} / \mathrm{mg}$ protein, respectively, and thus increases with age.

Studies have suggested that ACE not only converts $A \beta_{1-42}$ to $A \beta_{1-40}$ but can also cleave $A \beta_{1-40}$ into smaller fragments (20-22). Cerebral levels of $A \beta_{1-40}$ were measured by ELISA in 7-month-old 
A
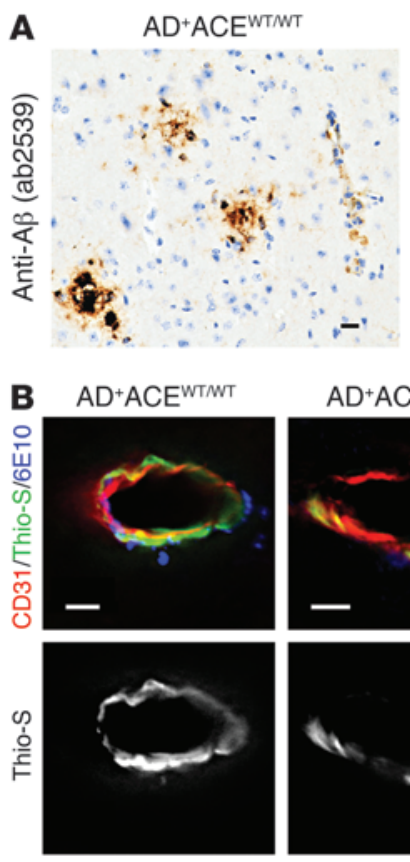
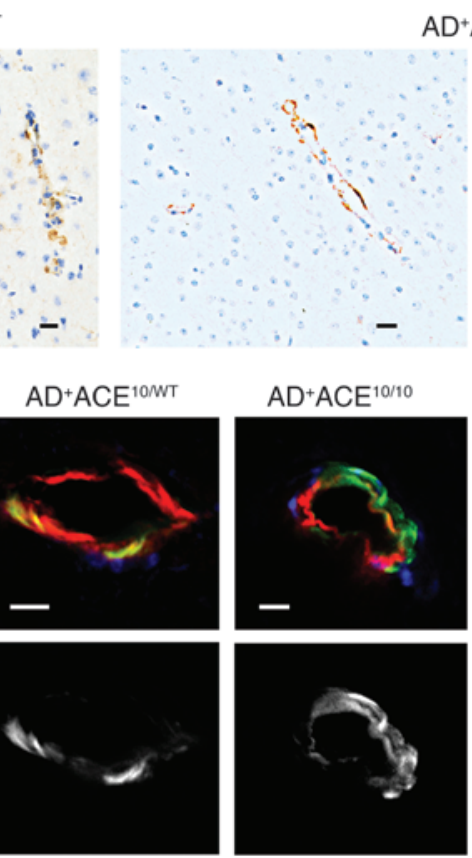

$A D^{+} A C E^{1 / 110}$

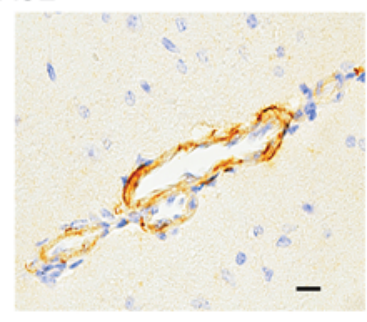

C

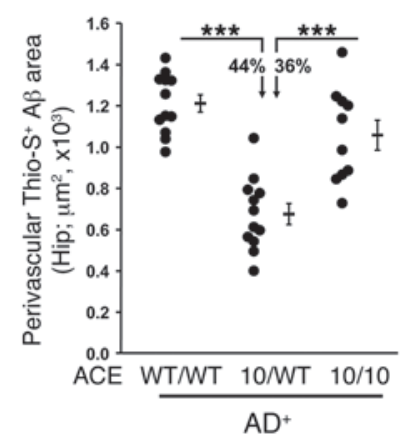

Figure 2

Perivascular $A \beta$ deposition in $A D^{+} A C E^{10 / W T}$ and $A D^{+} A C E^{10 / 10}$ mice. (A) Micrographs of paraffin sections from $A D^{+} A C E^{W T / W T}$ and $A D^{+} A C E^{10 / 10}$ cerebral cortex (8.5-month-old mice) labeled for human $A \beta$ using rabbit polyclonal antibody $A B 2539$ with standard peroxidase-based techniques. $A D^{+} A C E^{10 / 10}$ mice showed perivascular deposition of $A \beta$. (B) Representative images of fluorescence-based immunohistochemistry and Thio-S staining. PFA-fixed hippocampal sections of 7- to 8-month-old mice were colabeled with Thio-S (green), anti-CD31 (red), an EC marker, and 6E10 $\mathrm{mAb}$ (blue). The Thio-S signal is also shown in gray scale (lower panels). Scale bars: $10 \mu \mathrm{m}$. (C) Quantitation of perivascular Thio-S+ area in blood vessels from the hippocampus was performed using serial coronal sections. Data for individual mice as well as for group means and SEM are indicated, along with the percentages of reduction in the mean plaque area. Perivascular $A \beta$ deposition was significantly reduced in $\mathrm{AD}^{+} A C E^{10 / W T}$ mice compared with that in $\mathrm{AD}^{+} A C \mathrm{E}^{\mathrm{W} T} / \mathrm{WT}$ mice or $A D^{+} A C E^{10 / 10}$ mice. There was no statistical difference between the $A D^{+} A C E^{10 / 10}$ and $\mathrm{AD}^{+} \mathrm{ACE}{ }^{\mathrm{WT}} / \mathrm{WT}$ mice. $n=10-12$ mice per group. ${ }^{\star * \star} P<0.0001$.

$\mathrm{AD}^{+} \mathrm{ACE}{ }^{\mathrm{WT}} / \mathrm{WT}, \mathrm{AD}^{+} \mathrm{ACE}{ }^{10 / \mathrm{WT}}$, and $\mathrm{AD}^{+} \mathrm{ACE}^{10 / 10}$ mice (Figure 4D). This showed a significant reduction in $\mathrm{A} \beta_{1-40}$ levels in $\mathrm{AD}^{+} \mathrm{ACE} \mathrm{E}^{10 / \mathrm{WT}}$ and $\mathrm{AD}^{+} \mathrm{ACE} \mathrm{E}^{10 / 10}$ mice compared with those observed in $\mathrm{AD}^{+} \mathrm{ACE}{ }^{\mathrm{WT} / \mathrm{WT}}$ mice. The percentage reduction in $\mathrm{A} \beta_{1-40}$ was slightly less than the reduction in $A \beta_{1-42}$ levels (Figure $4 D$ vs. Figure $4 B$ ), possibly as a result of the conversion of $A \beta_{1-42}$ to $A \beta_{1-40}$ by ACE.

ACE inbibition. To further investigate the role of ACE in this model, $\mathrm{AD}^{+} \mathrm{ACE}^{10 / 10}$ mice were treated with the blood pressure-lowering drug ramipril, which is a specific inhibitor of ACE catalytic activity (48), or with hydralazine, which lowers blood pressure independently of ACE (Figure 5). The drugs were administered for either 28 or 60 days. Both drugs reduced systolic blood pressure, averaging $82 \mathrm{mmHg}$ in the mice treated with ramipril and $93 \mathrm{mmHg}$ in those treated with hydralazine. Mice treated for 28 days were 13.4 months of age on average when sacrificed, and mice treated for 60 days were 12.8 months of age on average when sacrificed.

We quantitated the plaque burden in brain sections of mice treated with ramipril or hydralazine for 60 days and compared this with plaque burden in age-matched, untreated $\mathrm{AD}^{+} \mathrm{ACE}$ WT/WT and $\mathrm{AD}^{+} \mathrm{ACE}{ }^{10 / 10}$ mice (Figure 5, $\mathrm{A}$ and $\mathrm{B}$, and Supplemental Figure 7). Even in 13-month-old mice, we found a significantly smaller plaque burden in the untreated $\mathrm{AD}^{+} \mathrm{ACE}^{10 / 10}$ mice than in the $\mathrm{AD}^{+} \mathrm{ACE}{ }^{\mathrm{WT} / \mathrm{WT}}$ mice. However, treatment of $\mathrm{AD}^{+} \mathrm{ACE}^{10 / 10}$ mice with the ACE inhibitor ramipril resulted in an increase of plaque burden as compared with that observed in untreated $\mathrm{AD}^{+} \mathrm{ACE}^{10 / 10}$ mice or $\mathrm{AD}^{+} \mathrm{ACE}^{10 / 10}$ mice treated with hydralazine. We also measured brain-insoluble and -soluble levels of $A \beta_{1-42}$ in the drug-treated mice (Figure 5, C and D) and found that insoluble $A \beta_{1-42}$ levels were equivalent in mice treated for 28 days with either ramipril or hydralazine. However, by 60 days, we observed that insoluble $A \beta_{1-42}$ levels were higher in the ramipril-treated mice than in the mice treated with hydralazine, consistent with the greater plaque burden seen in these animals (Figure 5B). Soluble $A \beta_{1-42}$ levels were also higher in the ramipril-treated $\mathrm{AD}^{+} \mathrm{ACE}^{10 / 10}$ mice as compared with those in equivalent mice treated with hydralazine (Figure $5 \mathrm{D})$, and we observed this in both the 28-day- and 60-day-treatment cohorts. Thus, in the $\mathrm{AD}^{+} \mathrm{ACE}^{10 / 10}$ mouse model, inhibiting ACE catalytic activity with ramipril markedly reduced the beneficial effects on plaque burden and on soluble and insoluble levels of $A \beta_{1-42}$ as compared with the effects seen in the hydralazine-treated mice.

Blood-borne monocytic cell infiltration and cellular A $\beta$ uptake. Cerebral inflammation is a prominent feature in AD. To assess the infiltration of blood-borne monocytic cells, we isolated and disassociated brains from age-matched 9.9- to 14.5-month-old $\mathrm{AD}^{+} \mathrm{ACE}{ }^{\mathrm{WT}} / \mathrm{WT}$ and $\mathrm{AD}^{+} \mathrm{ACE}^{10 / 10}$ mice. We then studied resident and peripherally derived inflammatory cells by flow cytometry after antibody labeling for the immune surface markers CD45, CD11b, and Ly6C $(49,50)$. Initial gating defined two populations: infiltrating hematopoietic cells (CD45 $\left.{ }^{\mathrm{hi}}\right)$ and microglia (CD11b ${ }^{+} \mathrm{CD} 45^{\text {lo-intermed }}$ ) (Supplemental Figure 8A). The CD45 ${ }^{\text {hi }}$ cells were further gated for CD $11 b^{+}$and $L y 6 C^{\text {hi }}$ expression (Supplemental Figure 8B). Several published studies indicate that $\mathrm{CD} 45^{\mathrm{hi}} \mathrm{Ly} 6 \mathrm{C}^{\mathrm{hi}} \mathrm{CD} 11 \mathrm{~b}^{+}$cells are monocytes originating from peripheral blood $(51,52)$. Quantification of these cells as a percentage of all $C D 11 \mathrm{~b}^{+}$cells showed a decrease in the percentage of these cells in $\mathrm{AD}^{+} \mathrm{ACE}^{10 / 10}$ mice as compared with that observed in $\mathrm{AD}^{+} \mathrm{ACE}{ }^{\mathrm{WT} / \mathrm{WT}}$ mice (Supplemental Figure $8 \mathrm{C}$ ). This is not surprising, given the substantial disease burden we observed in $\mathrm{AD}^{+} \mathrm{ACE} \mathrm{ET}^{\mathrm{WT} / \mathrm{WT}}$ mice and the reduction of this burden in $\mathrm{AD}^{+} \mathrm{ACE}{ }^{10 / 10}$ mice. Another way to assess infiltrating monocytic cells is to measure the CD $11 \mathrm{~b}^{+} \mathrm{Ly} 6 \mathrm{C}^{\text {hi }}$ cells as a percentage of total $\mathrm{CD} 11 \mathrm{~b}^{+}$cells. This assessment produced the same result of decreased inflammation in the $\mathrm{AD}^{+} \mathrm{ACE}^{10 / 10}$ mice (Supplemental Figure $8 \mathrm{D})$. Thus, the decreased $\mathrm{AD}$ we observed in $\mathrm{AD}^{+} \mathrm{ACE}^{10 / 10}$ mice (reduced plaque numbers, reduced astrogliosis, etc.) was also associated with a reduction in total cerebral inflammation. 

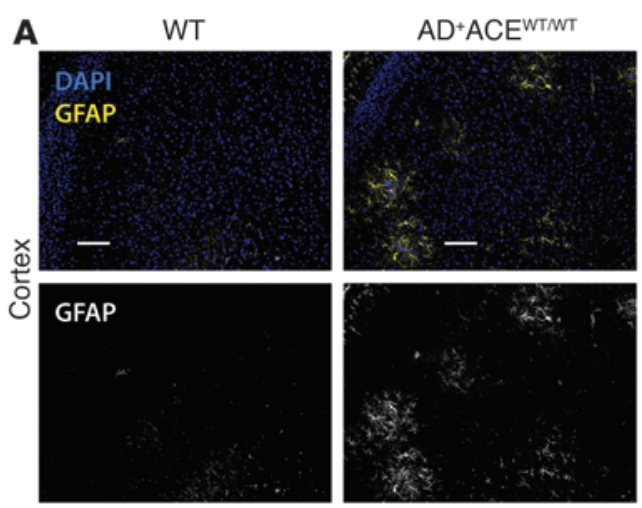

B

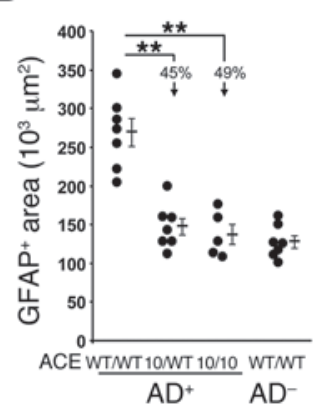

7 months

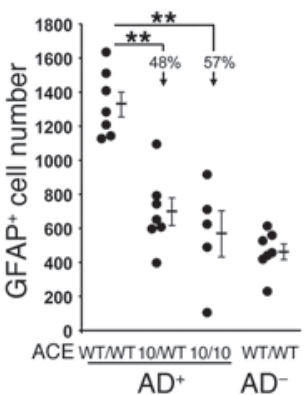

$\mathrm{AD}^{+} \mathrm{ACE}{ }^{10 \mathrm{WT}}$

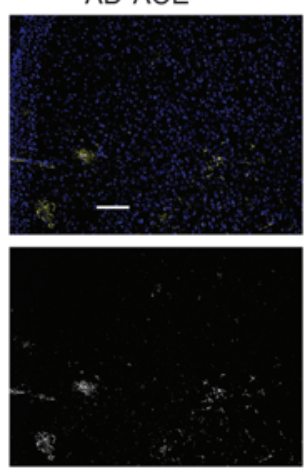

C

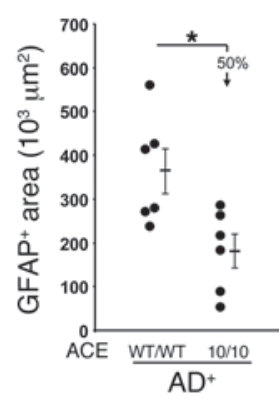

$\mathrm{AD}^{+} \mathrm{ACE}{ }^{10 / 10}$

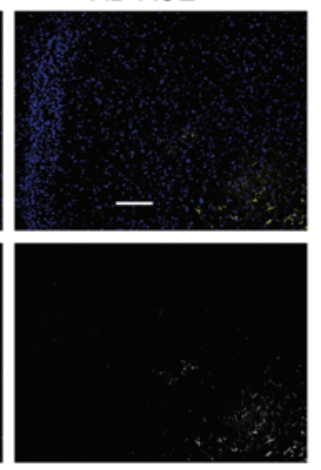

13 months

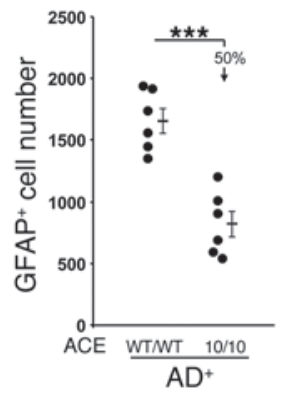

\section{Figure 3}

Reduced astrogliosis in $\mathrm{AD}^{+} \mathrm{ACE}{ }^{10 / 10}$ and $\mathrm{AD}^{+} \mathrm{ACE}{ }^{10 / \mathrm{WT}}$ mice. Coronal brain sections from 7- to- 8-monthold mice were stained with a polyclonal antibody against astrocyte-specific glial fibrillary acidic protein (GFAP; yellow). Sections were counterstained for nuclei with DAPI (blue). (A) Fluorescent micrographs of coronal brain sections show reduced staining for cortical GFAP in $\mathrm{AD}^{+}$mice heterozygous or homozygous for the $A C E 10$ allele $\left(A D^{+} A C E^{10 / W T}\right.$ and $\left.A D^{+} A C E^{10 / 10}\right)$. For simplicity of viewing, the bottom portion of panel A shows the GFAP channel as gray scale. Scale bars: $100 \mu \mathrm{m}$. (B) Quantitative analysis was performed to measure the GFAP+ area and cell numbers in 7- to 8-month-old mice. Data for individual mice are shown as well as for the group means and SEM. Arrows indicate the percentage of reduction in the group means as compared with that in $\mathrm{AD}^{+} A C E^{W T} / W^{T}$ mice. Mice heterozygous or homozygous for the ACE 10 allele had significantly reduced astrogliosis. (C) A similar analysis of astrogliosis was performed on 13-month-old mice. Even at this age, $A D^{+} A C E^{10 / 10}$ mice had significantly fewer $G F A P^{+}$reactive astrocytes than did $\mathrm{AD}^{+} \mathrm{ACE} \mathrm{WT}^{\mathrm{WT}}$ mice. $n=5-7$ mice per group. ${ }^{*} P<0.05 ;{ }^{* *} P<0.001 ;{ }^{* * *} P<0.0001$.

To further investigate the local immune changes in $\mathrm{AD}^{+}$mice, we performed immunohistochemistry on the brains of 7-monthold $\mathrm{AD}^{+} \mathrm{ACE} \mathrm{WT}^{\mathrm{WT} / \mathrm{WT}}, \mathrm{AD}^{+} \mathrm{ACE} \mathrm{E}^{10 / \mathrm{WT}}$, and $\mathrm{AD}^{+} \mathrm{ACE}^{10 / 10}$ mice (Figure 6, A-F). To help distinguish between resident microglia and peripheral monocytic cells, we used antibodies against the hematopoietic marker CD45, since infiltrating monocytes and macrophages show intense CD45 staining, while microglia have low-to-intermediate CD45 staining, even when activated $(49,53)$. We also costained brain sections with antibodies against ACE and human A $\beta$ (4G8) and found three features to be immediately apparent. First, most plaques present in the $\mathrm{AD}^{+} \mathrm{ACE} \mathrm{ET}^{\mathrm{WT} / \mathrm{WT}}$ mice were large, mature, and nondiffuse, while plaques present in the $\mathrm{AD}^{+} \mathrm{ACE}^{10 / 10}$ animals were generally smaller and less tightly organized (Figure 6, A and B). We also detected ACE expression in both microglia and monocytes and macrophages in $\mathrm{AD}^{+} \mathrm{ACE}^{10 / \mathrm{WT}}$ and $\mathrm{AD}^{+} \mathrm{ACE}^{10 / 10}$ mice and almost none in $\mathrm{AD}^{+} \mathrm{ACE} \mathrm{E}^{\mathrm{WT} / \mathrm{WT}}$ mice. Microglia are resident myelomonocytic lineage cells, and we observed moderate, punctate ACE staining in the ACE 10 model, while the monocytes and macrophages had very high ACE expression in addition to CD45hi expression. Finally, and most importantly, there was more association loid cells (36). Our data showed fewer such cells in the $\mathrm{AD}^{+} \mathrm{ACE}^{10 / 10}$ mice, but these data did not reach statistical significance. However, when we corrected this number for the total area of $6 \mathrm{E} 10^{+}$plaques to assess the number of infiltrating monocytic cells per plaque area, we found a significant increase in these numbers in the $\mathrm{AD}^{+} \mathrm{ACE}^{10 / 10}$ mice (Figure 6I). In summary, our microscopic analysis suggests that, in $\mathrm{AD}^{+} \mathrm{ACE}^{10 / 10}$ mice, the infiltrating cells are increasingly found to be associated with $A \beta$ plaque and are probably engaged in phagocytosis of $A \beta$.

Retained cognitive function by the Barnes maze test. While the $\mathrm{AD}^{+} \mathrm{ACE} \mathrm{E}^{10 / \mathrm{WT}}$ and $\mathrm{AD}^{+} \mathrm{ACE} \mathrm{E}^{10 / 10}$ mice have a reduced plaque burden, less astrogliosis, and lower amounts of soluble amyloidogenic $A \beta$ in the brain, the most crucial measure of resistance to $\mathrm{AD}$ progression is cognitive behavior. Spatial learning and memory were assessed in two separate cohorts of mice. One cohort of 11-month-old mice was tested by independent evaluators from the Cedars-Sinai Behavioral Core (Figure 7, A-F). A second cohort of 12-monthold mice was independently evaluated by members of our research group (Figure 8, A-F). All observers were blinded to the mouse genotype. The evaluators of each cohort arrived at the same conclusions. First, an open field test of ambulatory and rearing behavior 
A

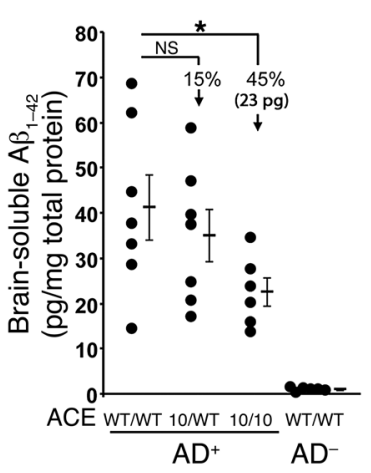

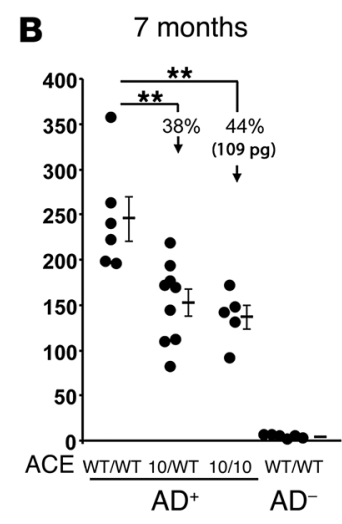

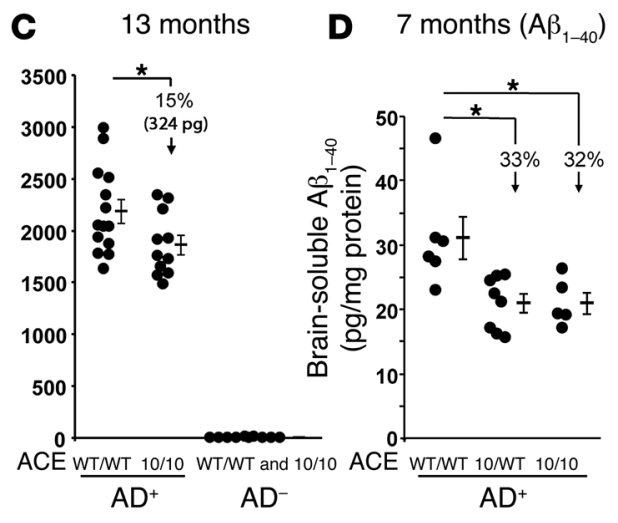

Figure 4

Reduced soluble $A \beta$ levels in $A D^{+} A C E^{10 / 10}$ and $A D^{+} A C E^{10 / W T}$ mice. (A-C) ELISA measurements of soluble human $A \beta_{1-42}$ in the brains of $A D^{+}$and $A D^{-}$mice with the indicated $A C E$ genotypes. Groups of mice were assessed at 5, 7, and 13 months of age. (D) ELISA measurement of soluble human $A \beta_{1-40}$ from 7-month-old $A D^{+} A C E^{W T / W T}, A D^{+} A C E^{10 / W T}$, and $A D^{+} A C E^{10 / 10}$ mice. Data for individual mice as well as for the group means and SEM are shown. Arrows indicate the percentage of reduction in the group means as compared with that in $A D^{+} A C E{ }^{W T} / W T$ mice. Also shown is the absolute reduction in $A \beta_{1-42}(23 \mathrm{pg}, 109 \mathrm{pg}$, and $324 \mathrm{pg}$ ) found in $A D^{+} A C E^{10 / 10}$ mice as compared with that seen in equivalently aged $A D^{+} A C E^{W T} /{ }^{N T}$ mice. Soluble levels of both $A \beta_{1-42}$ and $A \beta_{1-40}$ were lower in $A D^{+} A C E^{10 / 10}$ mice than in $A D^{+} A C E^{W T / W T}$ mice, as evidenced by the absolute reduction in $A \beta_{1-42}$ levels. The difference between $A D^{+} A C E^{10 / 10}$ and $A D^{+} A C E^{W T / W T}$ mice increased with age. $n=5-14$ mice per group. ${ }^{\star} P<0.05 ;{ }^{* \star} P<0.001$.

was performed to verify that the mice could be further assessed for cognitive function (Figure 7, A and B, and Figure 8, A and B). This test showed no significant differences between the groups, except for a mild increase in ambulatory activity of the 12-month-old $\mathrm{AD}^{+} \mathrm{ACE}{ }^{\mathrm{WT} / \mathrm{WT}}$ mice as compared with that of the $\mathrm{AD}^{-} \mathrm{ACE}^{\mathrm{WT} / \mathrm{WT}}$ mice (Figure 8A). Next, the mice were assessed using a Barnes maze, which tests hippocampal-based ability to learn and remember the location of an escape box using spatial cues (54-56). There was a training phase of 4 days, in which mice became progressively more efficient at finding the escape box (Figure 7C and Figure 8C), resulting in a shorter escape latency time. After a hiatus of 2 days, the mice were assessed for memory retention (day 7; Figure 7D and Figure 8D). This was followed on days 8 and 9 by the reversal phase, in which the position of the escape box was altered to test the ability of the mice to re-learn a new location. The analyses of two separate cohorts of mice by two different evaluating groups revealed that there was a marked difference in cognitive function, especially in the memory retention and reversal phases, between $\mathrm{AD}^{+} \mathrm{ACE} \mathrm{WT}^{\mathrm{WT}} / \mathrm{WT}$ mice and $\mathrm{AD}^{+} \mathrm{ACE} \mathrm{E}^{10 / \mathrm{WT}}$ or $\mathrm{AD}^{+} \mathrm{ACE}^{10 / 10}$ mice. The $\mathrm{AD}^{+} \mathrm{ACE} \mathrm{ET}^{\mathrm{WT} / \mathrm{WT}}$ mice demonstrated less cognitive ability to learn and retain the ability to solve the Barnes maze test (Figure 7, C-F, and Figure $8, \mathrm{C}-\mathrm{F}$ ). In contrast, the $\mathrm{AD}^{+} \mathrm{ACE}^{10 / \mathrm{WT}}$ and $\mathrm{AD}^{+} \mathrm{ACE}^{10 / 10}$ mice evaluated in Figure 7 and the $\mathrm{AD}^{+} A C E^{10 / 10}$ mice evaluated in Figure 8 demonstrated significantly improved cognitive behavior. In fact, mice having at least one ACE 10 allele showed maze-solving cognitive abilities that were not statistically different from those of control (WT) non-AD mice. Thus, not only does the presence of the ACE 10 allele reduce AD-like neuropathology, but it also appears to preserve cognitive ability.

\section{Discussion}

The goal of $\mathrm{AD}$ treatment is to retard or prevent the cognitive decline that is such a debilitating part of the disease. Thus, the results we obtained when $\mathrm{ACE}^{10 / 10}$ mice were crossed with $\mathrm{ADtg}$
A number of studies have shown that $\mathrm{ACE}^{10 / 10}$ mice have a marked enhancement of both their innate and adaptive immune responses. When challenged with a mouse model of melanoma, $\mathrm{ACE}^{10 / 10}$ mice showed an increased inflammatory response characterized by more aggressive monocyte and macrophage infiltration of the tumor (24). The result was a very substantial reduction in tumor growth. An enhanced innate immune response was also observed when $\mathrm{ACE}^{10 / 10}$ mice were challenged with L. monocytogenes or methicillin-resistant $S$. aureus (25). This appeared to be due to an intense monocytic/macrophagic response, and again, this resulted in reduced disease. While the precise biochemical details of how ACE changes the immune response are not yet known, a substantial feature is that ACE overexpression tilts the development of monocytes and macrophages toward a more inflammatory phenotype (57).

As compared with non- $\mathrm{AD}$ mice, we found that $\mathrm{AD}^{+} \mathrm{ACE}^{10 / \mathrm{WT}}$ and $\mathrm{AD}^{+} \mathrm{ACE}^{10 / 10}$ mice still had relatively high levels of cerebral-soluble and -insoluble A $\beta$. Yet, despite this, these mice had near-normal cognitive function, as measured by the Barnes maze test. A striking feature of the $\mathrm{AD}^{+} \mathrm{ACE} \mathrm{E}^{10 / \mathrm{WT}}$ and $\mathrm{AD}^{+} \mathrm{ACE}{ }^{10 / 10}$ mice is that, even at 13 months of age, these animals showed a significant decrease in insoluble and soluble $A \beta$ as compared with the levels seen in the $\mathrm{AD}^{+} \mathrm{ACE}{ }^{\mathrm{WT}} / \mathrm{WT}$ mice and that this was accompanied by a marked reduction in astrogliosis. This may help explain why the cognitive abilities of these genotypes were so well preserved.

Recently, there has been an appreciation that the inflammatory response, including the participation of blood-borne macrophages, can affect the progression of $\mathrm{AD}$. In particular, $\mathrm{BM}$-derived monocytic cells can infiltrate the brain and reduce $\mathrm{A} \beta$ plaque burden $(29-32,34,36,38-41,58)$. Macrophages readily absorb amyloid fibrils in vitro $(59,60)$ and seem more efficient than microglia at restricting $\mathrm{A} \beta$ plaques in models of $\mathrm{AD}$ $(30,31,36,38)$. ADtg mice immunized with glatiramer acetate or DCs loaded with the peptide MOG45D had an increased cerebral 

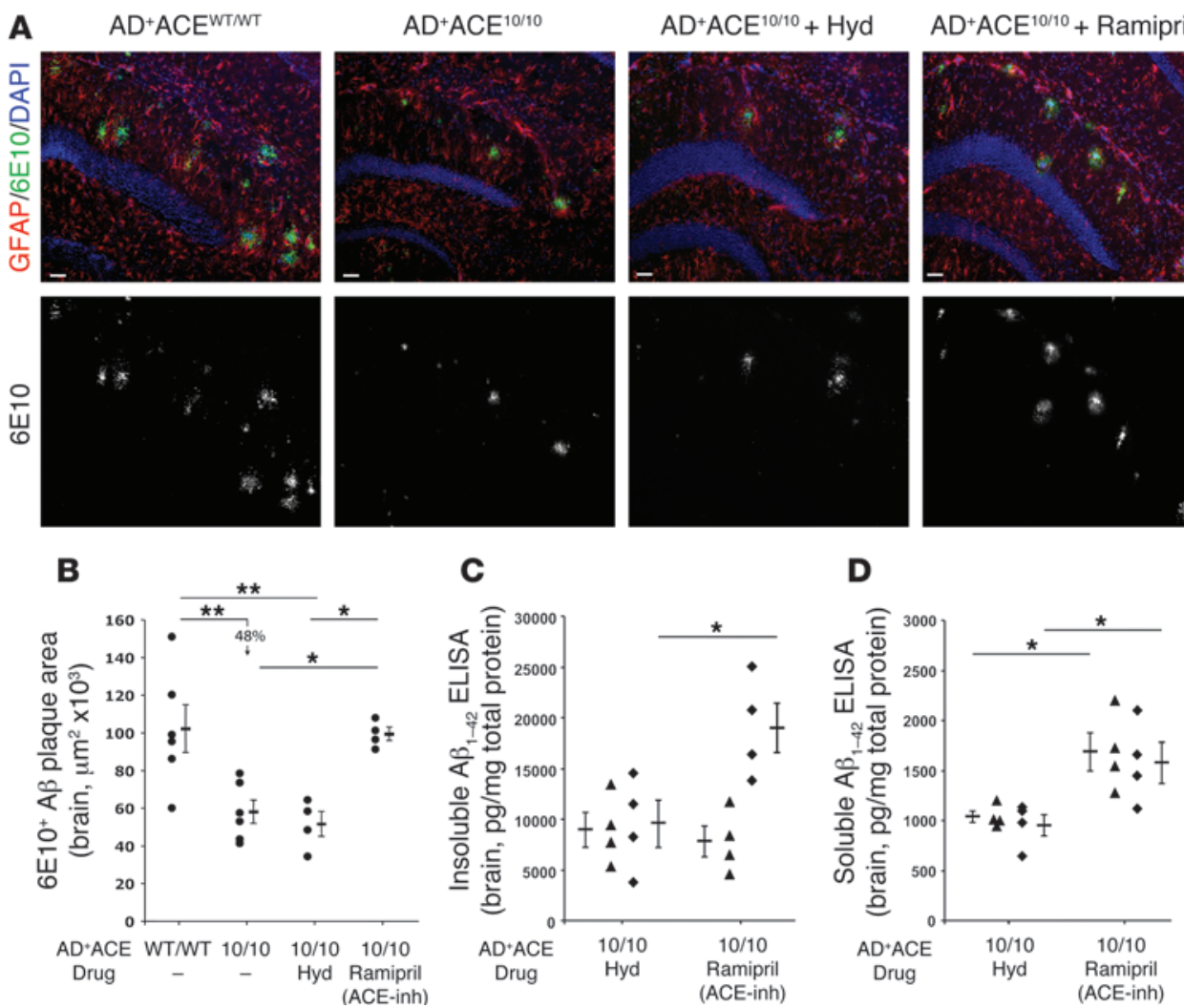

\section{Figure 5}

Effects of $A C E$ inhibition on brain $A \beta$ levels in $A D^{+} A C E^{10 / 10}$ mice. (A) Representative hippocampal micrographs from 13-month-old $A D^{+} A C E^{W T} / W T$ and $A D^{+} A C E^{10 / 10}$ mice as well as from $A D^{+} A C E^{10 / 10}$ mice treated for 60 days with either ramipril or hydralazine $(\mathrm{Hyd})$. Sections were stained with anti-human $A \beta$ antibody 6E10 (green), anti-GFAP (red), and DAPI (blue). Lower panels show the 6 E10 channel in gray scale. Scale bars: $50 \mu \mathrm{m}$. (B) Quantitative analysis of 6E10-positive immunoreactive plaque area from cortical and hippocampal regions. Data for individual mice, group means, and SEM are shown. ACE inhibition with ramipril significantly increased the plaque area as compared with that observed in $A D^{+} A C E^{10 / 10}$ mice or $A D^{+} A C E^{10 / 10}$ mice treated with hydralazine. ( $C$ and $\left.\mathbf{D}\right)$ Thirteen-month-old $A D^{+} A C E^{10 / 10}$ mice were treated for 28 days (black triangles) or 60 days (black diamonds) with ramipril or hydralazine. Measurement of insoluble human $A \beta_{1-42}$ by ELISA (C) showed no difference at 28 days between the mice receiving ramipril and those receiving hydralazine. However, after 60 days, the mice treated with ramipril had significantly higher insoluble $A \beta_{1-42}$ levels as compared with those in the hydralazine-treated group. Analysis of soluble $A \beta_{1-42}$ levels by ELISA (D) showed significantly higher brain levels at both 28 and 60 days in the $A D^{+} A C E^{10 / 10}$ mice treated with ramipril as compared with $A \beta_{1-42}$ levels in the equivalently aged mice treated with hydralazine. The mice treated with ramipril or hydralazine for 60 days in $\mathbf{C}$ and $\mathbf{D}$ were those studied in $\mathbf{A}$ and $\mathbf{B} .{ }^{*} P<0.05 ;{ }^{* \star} P<0.001$.

infiltration of monocytes that resulted in substantial attenuation of $\mathrm{AD}$ pathology $(31,36,61)$. These mice also had reduced cognitive impairment (62). Importantly, depletion of peripheral monocytic inflammatory cells or insufficient recruitment of BM-derived myeloid-derived cells to the brain led to accelerated AD pathology $(31,38)$. Taken together, these ideas led to our testing of the effect of the ACE ${ }^{10 / 10}$ phenotype in AD.

Our analysis of cerebral inflammation showed an overall lower number of blood-borne inflammatory monocytes in $\mathrm{AD}^{+} \mathrm{ACE}^{10 / 10}$ mice compared with that seen in $\mathrm{AD}^{+} \mathrm{ACE}{ }^{\mathrm{WT} / \mathrm{WT}}$ mice. This is not surprising, given the difference in pathology between the two genotypes. In addition, there was histologic evidence showing that in the $\mathrm{AD}^{+} \mathrm{ACE}^{10 / 10}$ mice, the $\mathrm{CD} 45^{\text {hi }} \mathrm{ACE}^{\text {hi }}$-expressing cells present in the brain associated with amyloid plaques in a manner suggesting an increase in the number of monocytic cells per plaque area and
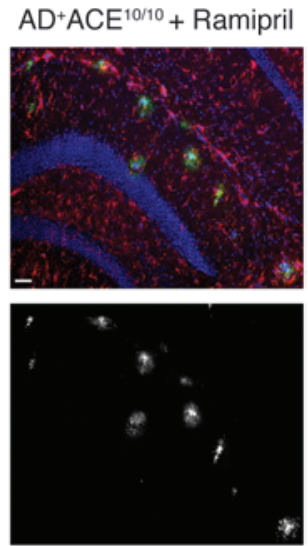

enhanced phagocytosis of amyloid. In the ACE ${ }^{10 / 10}$ model, both the IBA $1^{+} \mathrm{CD} 45^{\text {hi }}$ and the ACEhi phenotypes marked monocytic cells as originating in the BM. Thus, a more effective immune response of inflammatory cells overexpressing ACE can explain, at least in part, the beneficial phenotype observed in the $\mathrm{AD}^{+} \mathrm{ACE}^{10 / \mathrm{WT}}$ and $\mathrm{AD}^{+} \mathrm{ACE}^{10 / 10}$ mice.

There is a second feature of the $\mathrm{ACE}^{10 / 10}$ mice that should contribute to protection against AD. Several studies have identified ACE as being capable of cleaving a variety of amyloid peptides, including $A \beta_{1-42}$ and $A \beta_{1-40}$, into smaller fragments; at least in vitro, ACE can have both carboxypeptidic and endopeptidic activity against these larger amyloidogenic peptides (20-22, 63). In ACE $10 / 10$ mice, the serum levels of ACE are no different from WT mice. However, monocytes and macrophages express 16 -fold to more than 50-fold greater amounts of normal surface ACE (24). Thus, a second advantage of the ACE ${ }^{10 / 10}$ model in $\mathrm{AD}$ is the potential for enzymatic elimination of pathogenic peptides. In fact, our findings of reduced cerebral levels of $\mathrm{A} \beta$ in 5-, 7-, and 13-month-old $\mathrm{AD}^{+} \mathrm{ACE}^{10 / 10}$ mice are consistent with this hypothesis.

As shown in Figure 5, treatment of $\mathrm{AD}^{+} \mathrm{ACE} \mathrm{E}^{10 / 10}$ mice with the high-affinity and specific ACE catalytic inhibitor ramipril, known to cross the blood-brain barrier (48), significantly reduced the beneficial effects observed in this model (plaque burden and $A \beta_{1-42}$ levels) as compared with those seen with hydralazine treatment, a blood pressure-lowering drug that does not affect ACE. This is not surprising, since overexpression of catalytically active ACE is the key mechanistic feature of $\mathrm{ACE}^{10 / 10}$ mice, and previous studies have shown that $\mathrm{ACE}^{10 / 10}$ mice treated with ACE inhibitors exhibit the phenotype of WT mice $(24,25)$. In WT mice and humans, ACE is normally produced by vascular endothelium, but what role this plays in the biology of $A \beta$, including pathogenic forms such as $A \beta_{1-42}$, is not known. In our model, the analysis of perivascular $A \beta$ was striking in that $\mathrm{AD}^{+} \mathrm{ACE} \mathrm{E}^{10 / \mathrm{WT}}$ mice had substantially less perivascular $\mathrm{A} \beta$ than either $\mathrm{AD}^{+} \mathrm{ACE}^{\mathrm{WT} / \mathrm{WT}}$ or $\mathrm{AD}^{+} \mathrm{ACE}^{10 / 10}$ mice. This was surprising, since by all other measures, $\mathrm{AD}^{+} \mathrm{ACE}^{10 / 10}$ mice showed equal or less $\mathrm{AD}$ pathology. As mentioned, endothelium in $\mathrm{AD}^{+} \mathrm{ACE}^{10 / 10}$ mice produces no ACE, and it is possible that this contributes to more perivascular $A \beta$ in this genotype than in $\mathrm{AD}^{+} \mathrm{ACE}{ }^{10 / W T}$ mice, which produce some 
A

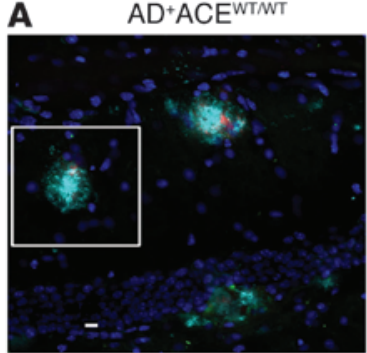

ACE
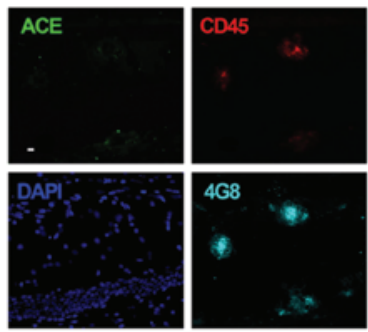

E $\quad A D^{+} A C E^{W T W T}$

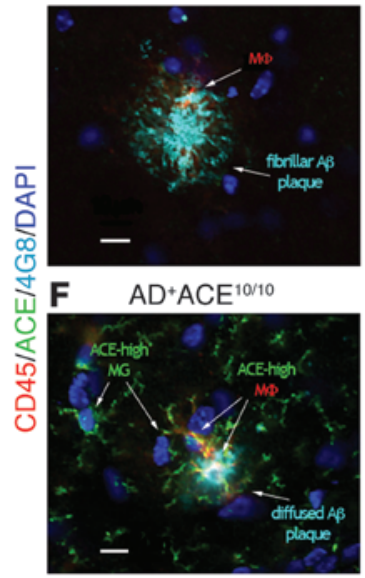

B
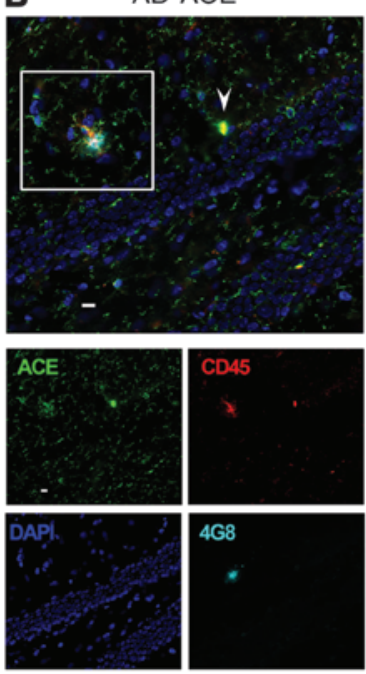

$A D^{+} A C E^{10 / 10}$
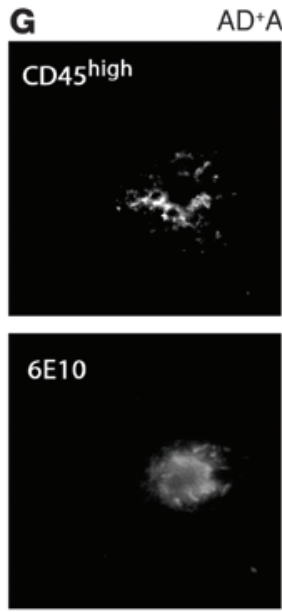
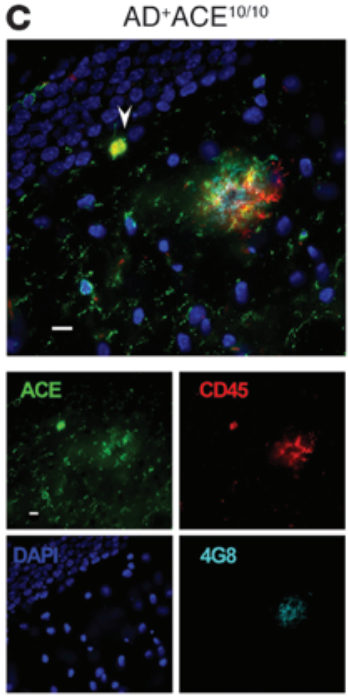

H
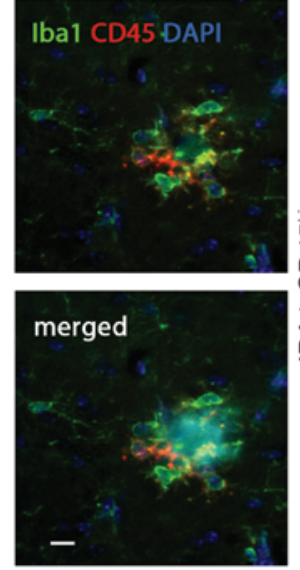

D $\quad \mathrm{AD}^{+} \mathrm{ACE}^{10 / \mathrm{WT}}$
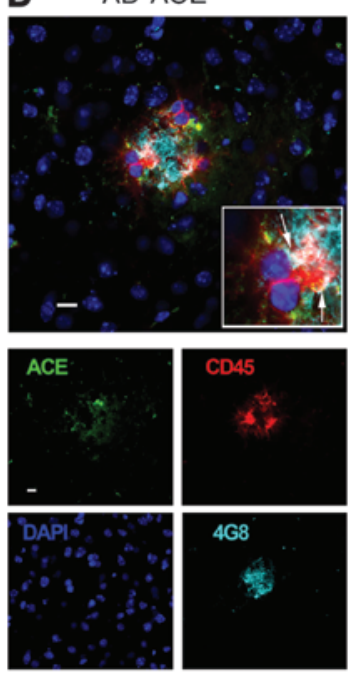

I
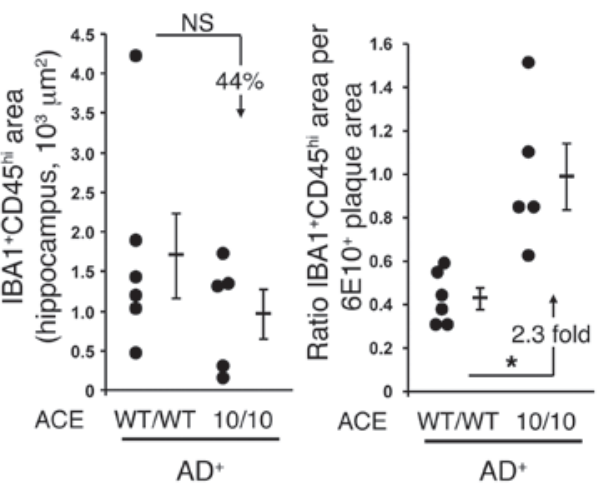

\section{Figure 6}

Infiltrating monocytic cells are increasingly associated with $A \beta$ plaque and cellular uptake of $A \beta$. (A-F) Fluorescent micrographs of hippocampal and cortical plaques from 7-month-old mice. Sections were immunolabeled for ACE (green), CD45 (red), human A $\beta$ (4G8; cyan), and nuclei (DAPI; blue). A-D show the composite picture and images from the individual color channels. (A) In $A D^{+} A C E^{W T} / W^{T}$ brains, the plaques were generally larger and composed of highly aggregated $A \beta$. CD $45^{\text {hi }} A C E^{l 0}$ cells were colocalized with amyloid plaques. (B and $\left.\mathbf{C}\right)$ In $A D+A C E^{10 / 10}$

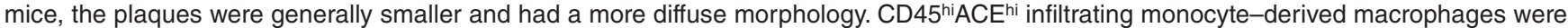
more frequently present in the vicinity of amyloid plaques. ACE was also expressed in the brain by resident CD45/o-intermedACEhi microglia. In $A D^{+} A C E^{10 / 10}$ mice, infiltrating monocytes expressed high levels of $A C E$ (arrowheads). (D) Cortical region from an $A D^{+} A C E^{10 / W T}$ mouse showed

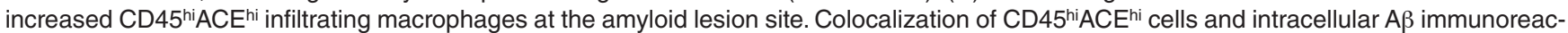
tivity (arrows in insert) were observed, indicating cellular uptake of $A \beta$. (E and $F$ ) Enlargements of boxed areas in $\mathbf{A}$ and $\mathbf{B}$. (F) In the $A D^{+} A C E^{10 / 10}$

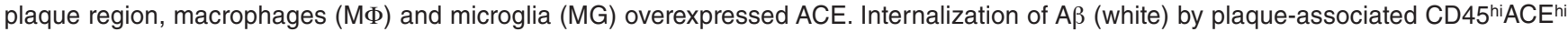
macrophages was observed. (G) Multichannel image shows recruitment of blood-derived IBA1+ (green) CD45 hi (red) macrophages to $6 E 10^{+}$ plaque (cyan) in $A D^{+} A C E^{10 / 10}$ brain. Scale bars: $10 \mu \mathrm{m}$. (H) Quantitation of IBA1+CD45 hi immunoreactive area. (I) The ratio of IBA1+CD45 ${ }^{\text {hi }}$ area to the 6 E10-immunoreactive area showed a significant increase (2.3-fold) in the number of macrophages per plaque area in $A D^{+} A C E^{10 / 10}$ versus that observed in $\mathrm{AD}^{+} \mathrm{ACE}{ }^{\mathrm{WT} / W T}$ mice. ${ }^{*} P<0.05$.

endothelial ACE due to the presence of one WT ACE allele. Further, the decreased perivascular $\mathrm{A} \beta$ we observed in $\mathrm{AD}^{+} \mathrm{ACE} \mathrm{E}^{10 / \mathrm{WT}}$ mice, together with the substantial reductions in soluble $A \beta$ and astrogliosis, may help explain why the cognitive abilities of this genotype, as measured by the Barnes maze test, were equivalent to those of both $\mathrm{AD}^{+} \mathrm{ACE}^{10 / 10}$ and non-AD mice.

Microglia differentiate from myeloid progenitor cells, and in the ACE ${ }^{10 / 10}$ mice, they expressed more ACE than WT microglia, but less ACE than monocytes and macrophages. When microglia from non-AD ACE ${ }^{10 / 10}$ brains were studied in vitro following exposure to LPS, they also appeared more inflammatory than similarly treated cells from ACE WT mice (Supplemental Figure 9). Additional experiments, including BM transfer, will be necessary to define the contribution of BM monocytes versus microglia in the $\mathrm{AD}^{+} \mathrm{ACE}{ }^{10 / 10}$ phenotype.

Several groups have studied the in vivo effect of natural levels of ACE on the incidence of $\mathrm{AD}$, and evidence has been presented both for and against the idea that natural ACE levels affect disease 
risk (20,64-67). Several meta-analyses have consistently found that lower serum and tissue ACE levels, as determined by an ACE gene polymorphism, were associated with a small increased risk of developing $\mathrm{AD}(68-71)$. On the other hand, recent genomewide association studies have failed to find involvement of ACE genetic variation in $\operatorname{AD}(64,72)$. However, these studies reflect an evaluation of the normal levels of ACE present in humans. As mentioned, we found that ACE expression in the ACE ${ }^{10 / 10}$ model was markedly increased, and it is likely that the catalytic activity of ACE, selectively expressed on the surface of macrophages and microglia, benefits the $\mathrm{AD}^{+} \mathrm{ACE} \mathrm{E}^{10 / 10}$ mice by reducing $\mathrm{A} \beta$ levels. This conclusion is supported by the higher brain $A \beta_{1-42}$ levels seen in mice treated with the ACE inhibitor ramipril as compared with the levels observed in mice treated with hydralazine. At the very least, our studies in ACE 10 mice emphasize the advantage of combining two separate approaches to reduce $A \beta$ burden in $\mathrm{AD}$ : an enhanced immune response resulting from ACE overexpression in monocytes and macrophages combined with the direct enzymatic effect of ACE in cleaving A $\beta$ peptides. The effect in the $\mathrm{AD}^{+} \mathrm{ACE}{ }^{10 / W T}$ and $\mathrm{AD}^{+} \mathrm{ACE}^{10 / 10}$ mice was a reduction of $A \beta$ plaques, soluble amyloidogenic $A \beta$, astrogliosis, and most remarkably, a retention of cognitive abilities that were virtually equivalent to those of non-AD mice.

Our study has limits, in that we did not evaluate the role of local angiotensin II production or angiotensin receptor expression in the mice heterozygous or homozygous for the ACE 10 allele. Also, we did not investigate the effects of this allele on the regulation of angiotensinogen. Several studies have suggested that angiotensin II AT1 receptor antagonists may be beneficial in AD by inhibiting the effects of angiotensin II, while permitting continued ACE cleavage of $A \beta$ (73). The precise role of angiotensin II in the mouse models we studied is not understood.

In $\mathrm{ACE}^{10 / 10}$ mice, activated macrophages have an enhanced inflammatory response (19). Use of monocytic cells overexpressing ACE in humans could conceivably have side effects. However, our evidence from the $\mathrm{AD}^{+} \mathrm{ACE}^{10 / 10}$ mice showed the opposite, namely, a decrease in overall cerebral inflammation. Also, ACE inhibitors would probably be an effective countermeasure, as ACE ${ }^{10 / 10}$ mice treated with such inhibitors have the phenotype of WT mice $(24,25)$. Further, we have never seen any evidence of autoimmune disease in $\mathrm{ACE}^{10 / 10}$ mice. While it is possible to envision a strategy for delivering ACE-overexpressing monocytes to patients, perhaps the most informative finding of our studies is the effectiveness of combining an approach to enhance the immune response with that of delivering inflammatory cells to enzymatically destroy $\mathrm{A} \beta$.

\section{Methods}

Mice. ACE ${ }^{10 / 10}$ mice have been previously described (24). In this strain, targeted homologous recombination was used to insert a $c$-fms promoter to direct tissue overexpression of ACE in myelomonocytic cells. The ACE genotypes are WT $\left(\mathrm{ACE}^{\mathrm{WT} / \mathrm{WT}}\right)$, heterozygous $\left(\mathrm{ACE}^{10 / \mathrm{WT}}\right)$, and homozygous for the targeted allele $\left(\mathrm{ACE}^{10 / 10}\right)$. These mice were backcrossed at least ten generations to C57BL/6J mice (The Jackson Laboratory).

The ADtg strain was originally purchased from The Jackson Laboratory (B6.Cg-Tg[APPswe,PSEN1dE9]85Dbo/J; stock no. 005864), then bred and maintained at Cedars-Sinai Medical Center. The Tgs contain familial AD mutations and are expressed in CNS tissue under the control of the mouse prion protein $(\operatorname{Pr} P)$ promoter. They contain cDNA sequences for the mutant human/mouse chimeric $\mathrm{A} \beta$ (A4) precursor protein (Swedish dou- ble mutations in $\left.\mathrm{APP}_{\mathrm{K} 595 \mathrm{~N}, \mathrm{M} 596 \mathrm{~L}}\right)$ and the exon 9 deletion of human presenilin $1\left(\mathrm{PS}_{\triangle \mathrm{Eg}}\right)(74)$. ADtg $\left(\mathrm{AD}^{+}\right.$; $\mathrm{C} 57 \mathrm{BL} / 6 \mathrm{~J}$ background) mice were crossed with $\mathrm{ACE}^{10 / 10}$ mice to produce the following genotypes: $\mathrm{AD}^{+} \mathrm{ACE} \mathrm{ET}^{\mathrm{WT} / \mathrm{WT}}$, $\mathrm{AD}^{+} \mathrm{ACE}^{10 / \mathrm{WT}}, \mathrm{AD}^{+} \mathrm{ACE}^{10 / 10}, \mathrm{AD}^{-} \mathrm{ACE}^{\mathrm{WT} / \mathrm{WT}}$, and $\mathrm{AD}^{-} \mathrm{ACE}^{10 / 10}$. The mice were genotyped for ACE (24), APP, and PS1 (36) alleles using conditions previously described. Age- and gender-matched mice for each genotype were assessed at various ages, ranging from 3 to 14 months. All mice were maintained in microisolator cages, and all experiments were conducted and recorded by researchers blinded to the mouse genotypes.

Blood pressure. Systolic blood pressure was measured in conscious $\mathrm{AD}^{+} \mathrm{ACE}{ }^{\mathrm{WT} / W \mathrm{~T}}$ and $\mathrm{AD}^{+} \mathrm{ACE}{ }^{10 / 10}$ mice using a Visitech tail cuff system (75). The individual blood pressure was the average of the blood pressure measured on 4 consecutive days following 4 days of training to accustom the animals to the procedure. Blood pressure from male and female mice was analyzed separately. The average age was similar for the two genotypes of mice.

Tissue processing. Following perfusion with ice-cold $0.9 \%$ saline containing $0.5 \mathrm{mM}$ EDTA, harvested brains were cut in half (36). One hemisphere was used for histology, and the second hemisphere was further cut into two halves and snap-frozen for biochemical and molecular assays.

Immunohistochemistry. For paraffin sections, tissues were fixed and embedded using standard techniques. Sections $(5 \mu \mathrm{m})$ were cut, deparaffinized, and placed in $88 \%$ formic acid for 5 minutes. After rinsing, the tissues were incubated at $\mathrm{pH} 9$ for 20 minutes, then rinsed and incubated for 15 minutes in buffer $\mathrm{pH} 7.6$ (Leica Biosystems, catalog AR9640) with either mouse mAb 6F/3D (1:800; Leica Biosystems) or a rabbit polyclonal anti-human $A \beta$ antibody (1:150; Ab2539; Abcam) targeting amino acids $1-14$. The secondary anti-mouse antibody and the DAB chromogen were dispensed using an automated Leica BONDIII slide-staining machine and Leica BOND Polymer Refine Detection reagents (Leica Biosystems, catalog DS9800). The secondary goat anti-rabbit antibody used was the Dako EnVision+ System-HRP Labeled Polymer (K4003; Dako). Standard peroxidase-based and H\&E staining techniques were used.

For immunofluorescence, the tissues were fixed in $2.5 \%$ PFA following dehydration with $30 \%$ sucrose. Coronal cryosections $(30 \mu \mathrm{m})$ were treated with Target Retrieval solution (Dako) at $95^{\circ} \mathrm{C}$ for 30 minutes. The tissues were then permeabilized and blocked as previously described (36). The sections were stained overnight at $4{ }^{\circ} \mathrm{C}$ with combinations of the following primary antibodies in PBS and blocking solution: mouse anti-human A $\beta$ mAb clone $6 \mathrm{E} 10$ (1:100; Covance) recognizing amino acids $1-16$ or mouse anti-human $\mathrm{A} \beta \mathrm{mAb}$ clone 4G8 (1:100; Covance) recognizing amino acids 17-24; rabbit anti-CD31 polyclonal antibody (1:50; Ab28364; Abcam); rabbit anti-GFAP polyclonal antibody (1:100; G9269; Sigma-Aldrich); rabbit anti-IBA1 (1:250; 019-19741; Wako); rabbit anti-ACE polyclonal antibody (1:500) (76); and rat anti-CD45 mAb (1:25; 550539; BD Pharmingen). Secondary polyclonal antibodies donkey anti-mouse, anti-rat, and anti-rabbit (1:200; Jackson ImmunoResearch Laboratories) conjugated with Cy-2, Cy-3, or DyLight 649 were incubated for 1 hour at $37^{\circ} \mathrm{C}$. Washing, DAPI nuclei staining, mounting, and microscopic analysis using an ApoTome-equipped Carl Zeiss Z1 fluorescence microscope were performed as previously described $(36,62)$. The specificity of the labeling was established by omitting the primary antibody from parallel brain sections.

A $\beta$ plaque staining by Thio-S. Following secondary antibody staining, brain sections were stained with Thio-S ( $1 \% \mathrm{w} / \mathrm{v}$ in $70 \%$ ethanol; Sigma-Aldrich) as previously described (36).

Quantitative immunohistochemistry. For each genotype, equivalent brain regions were analyzed. Coronal sections (3-6/mouse) were taken at $150-\mu \mathrm{m}$ intervals. For the analysis of $\mathrm{A} \beta$ plaque, $\mathrm{GFAP}^{+}$immunoreactive area, manual cell number counts, and IBA $1^{+} \mathrm{CD} 45^{\text {hi }}$ area and cell numbers, images were captured encompassing the hippocampal and cortical regions 
Open field test
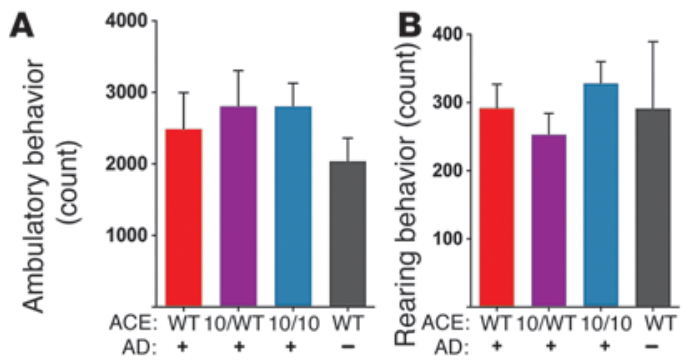

Barnes maze test
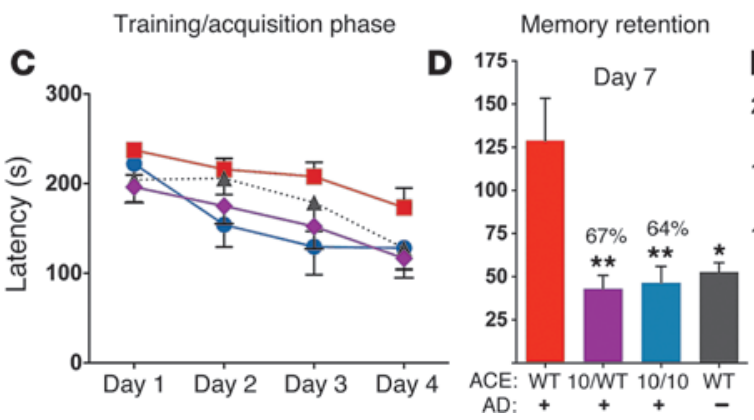

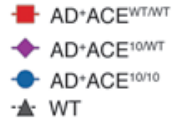

\section{Figure 7}

Preservation of cognitive function in 11-month-old $A D^{+} A C E^{10 / W T}$ and $A D^{+} A C E^{10 / 10}$ mice. Open field test assessing ambulatory $(\mathbf{A})$ and rearing $(\mathbf{B})$ behavior. No significant differences were observed. $(\mathbf{C}-\mathbf{F})$ Barnes maze assessment of spatial learning and memory. (C) During the training and acquisition phase, the mice became more efficient at finding and entering the escape box, resulting in reduced escape latency. Analysis by 2-way ANOVA showed a significant difference between genotypes $(P=0.0042)$. One-way ANOVA analysis of individual days 1-4 showed no significant differences between the genotypes. (D) A memory retention test was performed on day 7 after a hiatus of 2 days. The reduction in mean latency between $A D^{+} A C E^{10 / W T}$ and $A D^{+} A C E^{10 / 10}$ mice was $67 \%$ and $64 \%$, respectively, versus that of $A D^{+} A C E^{W T}{ }^{W T}$ mice. There was no statistical difference between $A D^{+} A C E^{10 / W T}$ or $A D^{+} A C E^{10 / 10}$ mice versus WT mice. (E and $F$ ) During the reversal phase (days 8 and 9), the location of the escape box was altered, and escape latency was measured. (E) Data analysis by 2 -way ANOVA showed a significant difference between genotypes $(P<0.0001)$. One-way ANOVA of days 8 and 9 showed significant differences between $A D^{+} A C E$ WT/WT and the other groups. Again, there was no statistical difference between $A D^{+} A C E^{10 / W T}$ or $A D^{+} A C E^{10 / 10}$ mice and WT mice. (F) On day 9 , the significant reduction in mean latency between $A D^{+} A C E^{10 / W T}$ or $A D^{+} A C E^{10 / 10}$ mice was $66 \%$ and $50 \%$, respectively, versus that of $\mathrm{AD}^{+} \mathrm{ACE} \mathrm{WT}^{\mathrm{W}} \mathrm{WT}$ mice. $n=6-10$ mice per group. ${ }^{\star} P<0.05 ;{ }^{* \star} P<0.001 ;{ }^{* \star \star} P<0.0001$.

and Pacific blue-conjugated antiLy6C (1:200; clone HK1.4). The stained samples were analyzed on a Beckman Coulter CyAn $\mathrm{ADP}$, and data were analyzed with FlowJo software (Tree Star, Inc.).

LPS-induced cytokine expression by microglia. Eight to 10-week-old $\mathrm{AD}^{-} \mathrm{ACE}^{\mathrm{WT} / \mathrm{WT}}$ and $\mathrm{AD}^{-} \mathrm{ACE}^{10 / 10}$ mice were perfused, and the brains were collected. Brains were chopped into small pieces and then digested for $30 \mathrm{~min}$ utes with $1.5 \mathrm{mg} / \mathrm{ml}$ collagenase IV and DNase I (STEMCELL Technologies) at $37^{\circ} \mathrm{C}$. After centrifugation, homogenization, and washing, the pellet was suspended in $70 \%$ Percoll and then layered under a 30\%/50\% Percoll step gradient. After centrifugation for 25 minutes at $700 \mathrm{~g}$, the cells at the interface of the $70 \%$ and $50 \%$ layers were collected, washed, and incubated in vitro for 6 hours with $5 \mu \mathrm{g} / \mathrm{ml}$ brefeldin A (eBioscience), with or without LPS (Escherichia coli 055:B5; Sigma-Aldrich) stimulation. Cells were then stained for the surface markers CD45 (1:200) and CD11b (1:100), followed by intracellular staining with PE-conjugated anti-IL-1 $\beta$ (1:333; clone NJTEN3; eBioscience) and APC-conjugated antiTNF- $\alpha$ (1:100; clone MP6-XT22; eBioscience). The CD $11 b^{+} \mathrm{CD}$ $45^{\text {lo-intermed }}$ microglia were evaluated for cytokine expression by flow cytometry.

(including entorhinal and cingulate cortex) using the same exposure times. For perivascular $A \beta$ deposition, areas of Thio-S and $6 \mathrm{E} 10$ colabeled with CD31 (a marker for vascular ECs) covering the hippocampal fissure in the outer molecular layer and vessels between the hippocampus and the mediorostral part of the lateral posterior thalamic nucleus were assessed in 5 to 7 serial brain sections per mouse, and the images were captured using the same exposure times. The images were then converted to gray scale and standardized to baseline using histogram-based thresholds in ImageJ software, versions $1.38 \mathrm{x}$ and $1.46 \mathrm{r}(\mathrm{NIH})$, as previously described $(36,77)$.

Analysis of cerebral inflammation by flow cytometry. The brains were perfused before harvest, then minced and digested for 30 minutes with $1.5 \mathrm{mg} / \mathrm{ml}$ collagenase IV (Worthington Biochemical Corp.) and DNase I (STEMCELL Technologies) at $37^{\circ} \mathrm{C}$. After centrifugation, homogenization, and washing, the pellet was suspended in 70\% Percoll (GE Healthcare) and then layered under a 30\%/50\% Percoll step gradient. After centrifugation for 25 minutes at $700 \mathrm{~g}$, the cells at the interface of the $70 \%$ and $50 \%$ layers were collected and washed. Cells were stained with the following antibodies purchased from eBioscience and BioLegend: FITC-conjugated anti-CD45 (1:200; clone 30-F11), PerCP/Cy5.5-conjugated anti-CD11b (1:100; clone M1/70),
Biochemical determination of $A \beta_{1-40}$ and $A \beta_{1-42}$ levels by sandwich ELISA. For brain-soluble and -insoluble ELISA analysis, brain tissues were homogenized in PBS buffer with $0.5 \%$ Triton X-100 and a $1 \mathrm{X}$ protease inhibitor cocktail set I (Calbiochem). After removal of cell debris, the homogenate was centrifuged at $10,000 \mathrm{~g}$ for 20 minutes at $4^{\circ} \mathrm{C}(36,61)$. The supernatant was considered the soluble fraction and was used to assess soluble $A \beta$. The pellet was diluted with the above homogenizing buffer. This was the insoluble fraction and was used to assess insoluble $A \beta$. After determination of the protein concentration (Thermo Fisher Scientific), soluble and insoluble Tg-derived $A \beta_{1-42}$ levels were determined using an anti-human $A \beta_{1-42}$ end-specific sandwich ELISA kit (KHB3442; Invitrogen) according to the manufacturer's instructions. This kit does not recognize mouse $A \beta$, nor does it recognize human $A \beta_{1-40}$, or $A \beta_{1-43}$. The kit uses two antibodies and is specific for the $\mathrm{N}$ - and $\mathrm{COOH}$-termini of the $\mathrm{A} \beta_{1-42}$ sequence; bound rabbit antibody was detected using an HRP-labeled anti-rabbit antibody and was read at $450 \mathrm{~nm}$ with a microplate reader (SpectraMax Plus384; Molecular Devices). Soluble $A \beta_{1-40}$ levels were measured using a similar Invitrogen ELISA kit (KHB3482). 
Open field test
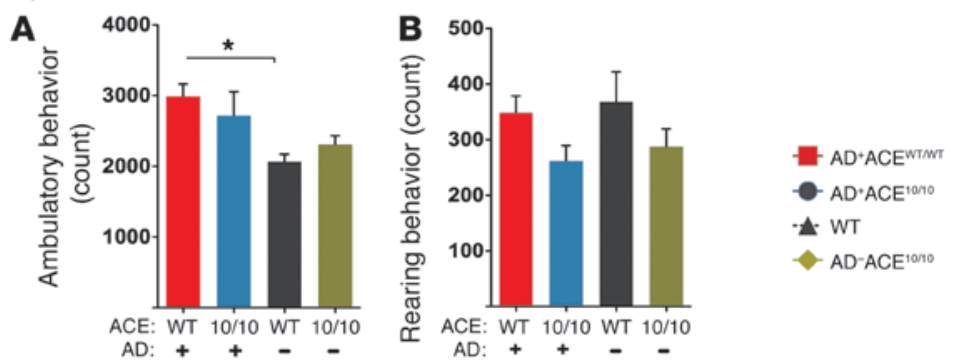

Barnes maze test

Training/acquisition phase
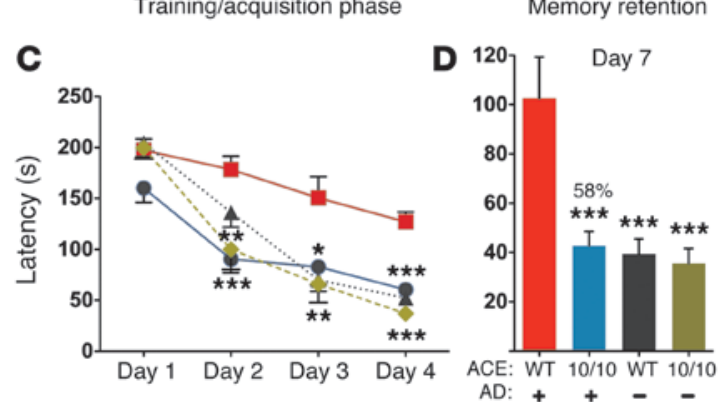

Reversal phase

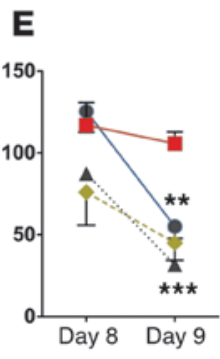

Figure 8

Retained cognition in 12-month-old $A D^{+} A C E^{10 / 10}$ mice. Open field test assessing ambulatory $(\mathbf{A})$ and rearing (B) behavior. Only the ambulatory count for $A D^{+} A C E^{W T} / W_{T}$ versus $A D^{-} A C E^{W T} /{ }^{W T}$ mice was significantly different. (C-F) Barnes maze assessment of spatial learning and memory following the same protocol as Figure 7. (C) Analysis of days 1-4 by 2-way ANOVA showed a significant difference between genotypes $(P<0.0001)$. Analysis of data from individual days by 1-way ANOVA showed significant differences between $A D^{+} A C E E^{W} / W T$ and $A D^{+} A C E^{10 / 10}$ mice. There was no significant difference between the $A D^{+} A C E^{10 / 10}$ mice and the two populations of non-AD control mice. (D) After a hiatus of 2 days, memory retention was assessed on day 7 . There was a $58 \%$ difference in the reduction of mean latency between $A D^{+} A C E^{10 / 10}$ and $A D^{+} A C E^{W T / W T}$ mice. No statistical difference was observed between $A D^{+} A C E^{10 / 10}$ mice and the two non-AD control groups. (E and F) During the reversal phase, the location of the escape box was changed, and escape latency was measured. Data analysis by 2-way ANOVA showed a significant difference between genotypes $(P<0.0001)$. Again, there was no statistical difference between $A D^{+} A C E^{10 / 10}$ mice and the two control groups. On day 8 , no significant differences were observed by 1-way ANOVA. Day 9 data analysis showed significant differences between AD+ACEWT/WT mice and the other groups. There was a $50 \%$ difference in the reduction of mean latency between the $A D^{+} A C E W T / W T$ and $\mathrm{AD}^{+} \mathrm{ACE}{ }^{10 / 10}$ mice. $n=10-11$ mice per group. ${ }^{\star} P<0.05 ;{ }^{\star \star} P<0.001 ;{ }^{\star \star \star} P<0.0001$.

Western blot analysis of APP. Snap-frozen forebrain samples (left hemibrains) were homogenized with a hand-held microgrinder (Argos Technologies) in RIPA buffer with a $1 \mathrm{X}$ protease inhibitor cocktail (Calbiochem). The homogenate was centrifuged at $10,000 \mathrm{~g}$ for 25 minutes at $4{ }^{\circ} \mathrm{C}$. The protein concentration was determined using a Bicinchoninic Acid Protein Assay kit (Pierce Biotechnology). Protein samples (40 $\mu \mathrm{g})$ were separated on Bis-Tris 4-12\% gel (Bio-Rad) with NuPAGE MOPS or MES buffer and transferred to $0.45-\mu \mathrm{m}$ nitrocellulose or PVDF membranes. The blots were probed with $6 \mathrm{E} 10 \mathrm{mAb}$ (1:1,000; anti-A $\beta$ $1-16$ aa; Covance) and were reprobed with anti- $\beta$-actin $\mathrm{mAb}(1: 1,000$; Sigma-Aldrich) as a loading control. The relative band intensity was quantified using ImageJ software, version 1.46r.

Brain ACE expression and activity. ACE activity and Western blotting were performed as previously described (78). For the preparation of protein extracts, the brains were collected from euthanized animals, weighed, and immediately frozen in liquid nitrogen. Later, they were gently homogenized in ACE buffer (50 mM HEPES, pH 7.4; $150 \mathrm{mM} \mathrm{NaCl} ; 25 \mu \mathrm{M} \mathrm{ZnCl}_{2}$; and $1 \mathrm{mM}$ PMSF). After centrifugation at $10,000 \mathrm{~g}$, the pellets were vigorously rehomogenized
Reversal phase

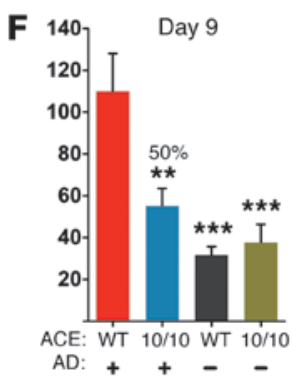

with ACE buffer containing $0.5 \%$ Triton $\mathrm{X}-100$. After a second centrifugation at $10,000 \mathrm{~g}$, the supernatant was collected and the protein concentration was measured with a BCA protein assay reagent kit (Pierce Biotechnology) according to the manufacturer's instructions. ACE activity was measured using the ACEREA kit from American Laboratory Products Company (ALPCO). ACE activity was defined as that inhibitable by captopril (Sigma-Aldrich).

For Western blotting, $20 \mu \mathrm{g}$ of total protein was separated by SDS-PAGE on a $10 \%$ gel and transferred to a $0.45-\mu \mathrm{m}$ nitrocellulose membrane. The membranes were probed with a 1:250 dilution of a rabbit polyclonal anti-mouse ACE antibody (76) and developed with a goat anti-rabbit IR dye $800 \mathrm{CW}$ (LI-COR Biosciences). The blot was scanned using the LI-COR Odyssey digital imaging system.

To inhibit $\mathrm{ACE}, \mathrm{AD}^{+} \mathrm{ACE}^{10 / 10}$ mice were treated for 28 days or 60 days with $160 \mathrm{mg} /$ liter of drinking water of either the ACE inhibitor ramipril (NDC 16252-573-01; Watson) or hydralazine (Sigma-Aldrich), which lowers blood pressure independently of ACE.

Open field test. The open field test was performed as previously described (79). Briefly, mice were placed individually in the open field apparatus (San Diego Instruments), with ambulatory and rearing activity measured for $60 \mathrm{~min}$ utes after at least 1 hour of habituation. Ambulatory activity was recorded when the mouse broke successive lower beams within a 1 -second period. Rearing behavior was counted when an upper beam was broken.

Barnes maze test. The Barnes maze apparatus consisted of a flat white circular platform with 20 equally spaced holes around the circumference. One of the 20 holes led to an escape box, while the other 19 led to false boxes that were too small to be entered $(2 \mathrm{~cm}$ below the surface area of the platform). The test were conducted in three phases. In the training and acquisition phase, the escape box was placed under 1 of the 20 holes. Animals were first placed into an opaque cylinder at the center of the maze for 30 seconds to promote initial spatial disorientation. After 30 seconds, the cylinder was removed, and the animal explored the maze until it found and entered the escape box. The escape latency was the duration of time between removal of the cylinder and animal entry into the escape box. Two bright lights illuminated the center of the Barnes platform. If the mouse failed to enter the escape box within 240 seconds, the experimenter gently led it into the escape box. The animal remained in the escape box for an additional 30 seconds before it was removed and returned to the home cage. The escape box, additional boxes, and maze surface were sprayed with $70 \%$ isopropyl alcohol and wiped in a nonsystematic fashion to dissipate and disseminate odor cues for subsequent trials. The location 
of the escape box remained the same for a mouse during every trial of the training phase, but was shifted between mice to reduce the potential for unintended intramaze cues. Training was repeated three times per day, with a 15 -minute interval separating each trial. Data from each trial were recorded and averaged. The training phase was conducted for 4 days, followed by a 2-day break with no exposure to the maze. On day 7 , each animal was re-tested in a three-trial session using the same escape box location and method from the training phase. On day 8 following the retention phase, the reversal phase began, in which the escape box was placed in a different quadrant than the original escape box location. Using the same procedure as above, reversal trials were repeated three times per day over two consecutive days (days 8 and 9). Data were recorded both manually and by a video camera located above the maze.

Statistics. Data were analyzed using GraphPad Prism software, version $5.0 \mathrm{~b}$ (GraphPad Software). Values are presented for the individual mice and/or expressed as the means \pm SEM. ANOVA with Tukey's post-hoc tests were used for multiple comparisons. The behavioral data were analyzed using both repeated-measures 2-way and 1-way ANOVA with Tukey's posthoc tests for each day. Two-group comparisons were analyzed by 2-tailed, unpaired Student's $t$ tests. A $P$ value of less than 0.05 was considered statistically significant.

Study approval. All experimental protocols were approved by and conducted according to the instructions of the IACUC of Cedars-Sinai Medical Center.

\section{Acknowledgments}

This study was supported by NIH grants R00 HL088000 and R01 HL110353; the Coins for Alzheimer's Research Trust (CART) Fund; the BrightFocus Foundation (formerly the AHAF); the Maurice Marciano Family Foundation; the American Heart Association (Beginning Grant-in-Aid 13BGIA14680069); and the National Center for Advancing Translational Sciences through CTSI (UL1TR000124). The authors thank Robert N. Pechnick and Catherine Farrokhi for help with behavioral studies. We also thank Fai Chung and Evelyn Kim for help with immunohistochemistry on paraffin sections and Tea Janjulia for help in measuring blood pressure. The authors dedicate the manuscript to the memory of Natalie Radom Bernstein, who died April 9, 2013, Lillian Jones Black, who died May 24, 2012, and Salomon Moni Hamaoui, who died March 6, 1994, all of AD.

Received for publication August 24, 2012, and accepted in revised form November 18, 2013.

Address correspondence to: Maya Koronyo-Hamaoui, CedarsSinai Medical Center, 127 S. San Vicente Blvd., Los Angeles, California 90048, USA. Phone: 310.423.7473; Fax: 424.315.4569; E-mail: maya.koronyo@cshs.org.
1. Brookmeyer R, et al. National estimates of the prevalence of Alzheimer's disease in the United States. Alzheimers Dement. 2011;7(1):61-73.

2. Selkoe DJ. Alzheimer's disease results from the cerebral accumulation and cytotoxicity of amyloid beta-protein. J Alzheimers Dis. 2001;3(1):75-80.

3. Hardy J, Selkoe DJ. The amyloid hypothesis of Alzheimer's disease: progress and problems on the road to therapeutics. Science. 2002; 297(5580):353-356

4. Rufenacht P, Guntert A, Bohrmann B, Ducret A, Dobeli H. Quantification of the $A \beta$ peptide in Alzheimer's plaques by laser dissection microscopy combined with mass spectrometry. J Mass Spectrom. 2005;40(2):193-201.

5. Shankar GM, et al. Amyloid- $\beta$ protein dimers isolated directly from Alzheimer's brains impair synaptic plasticity and memory. Nat Med. 2008; 14(8):837-842.

6. Zhang H, Ma Q, Zhang YW, Xu H. Proteolytic processing of Alzheimer's $\beta$-amyloid precursor protein. J Neurochem. 2012;120(suppl 1):9-21.

7. Selkoe DJ. Soluble oligomers of the amyloid $\beta$-protein impair synaptic plasticity and behavior. Behav Brain Res. 2008;192(1):106-113.

8. Akiyama H, et al. Inflammation and Alzheimer's disease. Neurobiol Aging. 2000;21(3):383-421.

9. Bales KR, Du Y, Holtzman D, Cordell B, Paul SM. Neuroinflammation and Alzheimer's disease: critical roles for cytokine/A $\beta$-induced glial activation, NF-KB, and apolipoprotein E. Neurobiol Aging. 2000; 21(3):427-432.

10. McGeer PL, McGeer EG. Local neuroinflammation and the progression of Alzheimer's disease. J Neurovirol. 2002;8(6):529-538.

11. Wyss-Coray T. Inflammation in Alzheimer disease: driving force, bystander or beneficial response? Nat Med. 2006;12(9):1005-1015.

12. Selkoe DJ. Normal and abnormal biology of the $\beta$-amyloid precursor protein. Annu Rev Neurosci. 1994;17:489-517.

13. Saido TC. Alzheimer's disease as proteolytic disorders: anabolism and catabolism of $\beta$-amyloid. Neurobiol Aging. 1998;19(1 suppl):S69-S75.

14. De Felice FG, Ferreira ST. Beta-amyloid production, aggregation, and clearance as targets for therapy in Alzheimer's disease. Cell Mol Neurobiol. 2002;
22(5-6):545-563

15. Mawuenyega KG, et al. Decreased clearance of CNS $\beta$-amyloid in Alzheimer's disease. Science. 2010; 330(6012):1774.

16. Lee EB, et al. Targeting amyloid- $\beta$ peptide (Abeta) oligomers by passive immunization with a conformation-selective monoclonal antibody improves learning and memory in $A \beta$ precursor protein (APP) transgenic mice. J Biol Chem. 2006;281(7):4292-4299.

17. Nitsch RM, Hock C. Targeting $\beta$-amyloid pathology in Alzheimer's disease with $A \beta$ immunotherapy. Neurotherapentics. 2008;5(3):415-420.

18. Cho JE, Kim JR. Recent approaches targeting $\beta$-amyloid for therapeutic intervention of Alzheimer's disease. Recent Pat CNS Drug Discov. 2011; $6(3): 222-233$.

19. Bernstein KE, et al. A modern understanding of the traditional and nontraditional biological functions of angiotensin-converting enzyme. Pharmacol Rev. 2013;65(1):1-46.

20. Hemming ML, Selkoe DJ. Amyloid $\beta$-protein is degraded by cellular angiotensin-converting enzyme (ACE) and elevated by an ACE inhibitor. J Biol Chem. 2005;280(45):37644-37650.

21 . Zou K, et al. A $\beta 42$-to-A $\beta 40$ - and angiotensin-converting activities in different domains of angiotensin-converting enzyme. J Biol Chem. 2009; 284(46):31914-31920.

22. Zou K, et al. Angiotensin-converting enzyme converts amyloid $\beta$-protein 1-42 (A $\beta(1-42))$ to $A \beta(1-40)$, and its inhibition enhances brain $\mathrm{A} \beta$ deposition. J Neurosci. 2007;27(32):8628-8635.

23. Harmer D, Gilbert M, Borman R, Clark KL. Quantitative mRNA expression profiling of ACE 2 , a novel homologue of angiotensin converting enzyme. FEBS Lett. 2002;532(1-2):107-110.

24. Shen XZ, et al. Mice with enhanced macrophage angiotensin-converting enzyme are resistant to melanoma. Am J Pathol. 2007;170(6):2122-2134.

25. Okwan-Duodu D, et al. Angiotensin-converting enzyme overexpression in mouse myelomonocytic cells augments resistance to Listeria and methicillin-resistant Staphylococcus aureus. J Biol Chem. 2010;285(50):39051-39060.

26. Shen XZ, et al. The carboxypeptidase ACE shapes the MHC class I peptide repertoire. Nat Immunol. 2011;12(11):1078-1085.
27. Colton CA, Chernyshev ON, Gilbert DL, Vitek MP. Microglial contribution to oxidative stress in Alzheimer's disease. Ann N Y Acad Sci. 2000; 899:292-307.

28. D'Andrea MR, Cole GM, Ard MD. The microglial phagocytic role with specific plaque types in the Alzheimer disease brain. Neurobiol Aging. 2004; 25(5):675-683.

29. Malm TM, et al. Bone-marrow-derived cells contribute to the recruitment of microglial cells in response to $\beta$-amyloid deposition in APP/PS1 double transgenic Alzheimer mice. Neurobiol Dis. 2005; 18(1):134-142.

30. Simard AR, Soulet D, Gowing G, Julien JP, Rivest $\mathrm{S}$. Bone marrow-derived microglia play a critical role in restricting senile plaque formation in $\mathrm{Alz}$ heimer's disease. Neuron. 2006;49(4):489-502.

31. Butovsky O, Kunis G, Koronyo-Hamaoui M, Schwartz M. Selective ablation of bone marrow-derived dendritic cells increases amyloid plaques in a mouse Alzheimer's disease model. Eur J Neurosci. 2007;26(2):413-416.

32. Fiala M, Cribbs DH, Rosenthal M, Bernard G. Phagocytosis of amyloid- $\beta$ and inflammation: two faces of innate immunity in Alzheimer's disease. J Alzheimers Dis. 2007;11(4):457-463.

33. Cameron B, Landreth GE. Inflammation, microglia, and Alzheimer's disease. Neurobiol Dis. 2010; 37(3):503-509.

34. Lai AY, McLaurin J. Clearance of amyloid- $\beta$ peptides by microglia and macrophages: the issue of what, when and where. Future Neurol. 2012; $7(2): 165-176$.

35. Mizuno T. The biphasic role of microglia in Alzheimer's disease. Int J Alzheimers Dis. 2012; 2012:737846.

36. Koronyo-Hamaoui M, et al. Attenuation of ADlike neuropathology by harnessing peripheral immune cells: local elevation of IL-10 and MMP-9. J Neurochem. 2009;111(6):1409-1424.

37. Simard AR, Rivest S. Neuroprotective properties of the innate immune system and bone marrow stem cells in Alzheimer's disease. Mol Psychiatry. 2006; 11(4):327-335.

38. El Khoury J, et al. Ccr2 deficiency impairs microglial accumulation and accelerates progression of Alzheimer-like disease. Nat Med. 2007;13(4):432-438. 
39. Schwartz M, Shechter R. Systemic inflammatory cells fight off neurodegenerative disease. Nat Rev Neurol. 2010;6(7):405-410.

40. Lebson L, et al. Trafficking CD11b-positive blood cells deliver therapeutic genes to the brain of amyloid-depositing transgenic mice. J Neurosci. 2010; 30(29):9651-9658

41. Hickman SE, El Khoury J. Mechanisms of mononuclear phagocyte recruitment in Alzheimer's disease. CNS Neurol Disord Drug Targets. 2010;9(2):168-173.

42. Jankowsky JL, et al. Mutant presenilins specifically elevate the levels of the 42 residue $\beta$-amyloid peptide in vivo: evidence for augmentation of a 42-specific $\gamma$ secretase. Hum Mol Genet. 2004; 13(2):159-170.

43. Chakrabarty $\mathrm{P}$, et al. IFN- $\gamma$ promotes complement expression and attenuates amyloid plaque deposition in amyloid beta precursor protein transgenic mice. J Immunol. 2010;184(9):5333-5343.

44. Garcia-Alloza M, et al. Characterization of amyloid deposition in the APPswe/PS1dE9 mouse model of Alzheimer disease. Neurobiol Dis. 2006;24(3):516-524

45. Miao J, et al. Reducing cerebral microvascular amyloid- $\beta$ protein deposition diminishes regional neuroinflammation in vasculotropic mutant amyloid precursor protein transgenic mice. J Neurosci. 2005;25(27):6271-6277.

46. Akiyama $\mathrm{H}$, et al. Cell mediators of inflammation in the Alzheimer disease brain. Alzheimer Dis Assoc Disord. 2000;14(suppl 1):S47-S53.

47. Wyss-Coray T, Mucke L. Inflammation in neurodegenerative disease - a double-edged sword. Neuron. 2002;35(3):419-432.

48. Gohlke P, Scholkens B, Henning R, Urbach H, Unger $\mathrm{T}$. Inhibition of converting enzyme in brain tissue and cerebrospinal fluid of rats following chronic oral treatment with the converting enzyme inhibitors ramipril and Hoe 288. J Cardiovasc Pharmacol. 1989;14(Suppl 4):S32-S36.

49. Prinz M, Priller J, Sisodia SS, Ransohoff RM Heterogeneity of CNS myeloid cells and their roles in neurodegeneration. Nat Neurosci. 2011; 14(10):1227-1235

50. Savino B, et al. Control of murine Ly6C(high) monocyte traffic and immunosuppressive activi ties by atypical chemokine receptor D6. Blood. 2012; 119(22):5250-5260.

51. Marques CP, et al. Prolonged microglial cell activation and lymphocyte infiltration following experimental herpes encephalitis. JImmunol. 2008; 181(9):6417-6426.

52 . Wohleb ES, et al. $\beta$-Adrenergic receptor antagonism prevents anxiety-like behavior and microglial reactivity induced by repeated social defeat.
Neurosci. 2011;31(17):6277-6288.

53. Juedes AE, Ruddle NH. Resident and infiltrating central nervous system APCs regulate the emergence and resolution of experimental autoimmune encephalomyelitis. J Immunol. 2001;166(8):5168-5175.

54. O'Leary TP, Brown RE. Visuo-spatial learning and memory deficits on the Barnes maze in the 16-month-old APPswe/PS1dE9 mouse model of Alzheimer's disease. Behav Brain Res. 2009; 201(1):120-127.

55. Reiserer RS, Harrison FE, Syverud DC, McDonald MP. Impaired spatial learning in the APPSwe + PSEN1DeltaE9 bigenic mouse model of Alzheimer's disease. Genes Brain Behav. 2007;6(1):54-65.

56. Walker JM, et al. Spatial learning and memory impairment and increased locomotion in a transgenic amyloid precursor protein mouse model of Alzheimer's disease. Behav Brain Res. 2011; 222(1):169-175.

57. Shen $X Z$, et al. Nontraditional roles of angiotensin-converting enzyme. Hypertension. 2012; 59(4):763-768.

58. Boissonneault $\mathrm{V}$, et al. Powerful beneficial effects of macrophage colony-stimulating factor on $\beta$-amyloid deposition and cognitive impairment in Alzheimer's disease. Brain. 2009;132(pt 4):1078-1092.

59. Paresce DM, Ghosh RN, Maxfield FR. Microglial cells internalize aggregates of the Alzheimer's disease amyloid $\beta$-protein via a scavenger receptor. Neuron. 1996;17(3):553-565.

60. Webster SD, et al. Complement component C1q modulates the phagocytosis of $\mathrm{A} \beta$ by microglia. Exp Neurol. 2000;161(1):127-138.

61. Bakalash S, et al. Egr1 expression is induced following glatiramer acetate immunotherapy in rodent models of glaucoma and Alzheimer's disease. Invest Ophthalmol Vis Sci. 2011;52(12):9033-9046.

62. Butovsky $\mathrm{O}$, et al. Glatiramer acetate fights against Alzheimer's disease by inducing dendritic-like microglia expressing insulin-like growth factor 1 . Proc Natl Acad Sci U S A. 2006;103(31):11784-11789.

63. Sun X, et al. Catabolic attacks of membrane-bound angiotensin-converting enzyme on the $\mathrm{N}$-terminal part of species-specific amyloid- $\beta$ peptides. Eur J Pharmacol. 2008;588(1):18-25.

64. Kehoe PG, Miners S, Love S. Angiotensins in Alzheimer's disease - friend or foe? Trends Neurosci. 2009;32(12):619-628.

65. Kehoe PG. Angiotensins and Alzheimer's disease: a bench to bedside overview. Alzheimers Res Ther. 2009;1(1):3

66. Miners JS, et al. Angiotensin-converting enzyme (ACE) levels and activity in Alzheimer's disease, and relationship of perivascular ACE-1 to cerebral amy- loid angiopathy. Neuropathol Appl Neurobiol. 2008; 34(2):181-193.

67. Hemming ML, Selkoe DJ, Farris W. Effects of prolonged angiotensin-converting enzyme inhibitor treatment on amyloid $\beta$-protein metabolism in mouse models of Alzheimer disease. Neurobiol Dis. 2007;26(1):273-281.

68. Kehoe PG, et al. Common variants of ACE contribute to variable age-at-onset of Alzheimer's disease. Hum Genet. 2004;114(5):478-483.

69. Kolsch H, et al. ACE I/D polymorphism is a risk factor of Alzheimer's disease but not of vascular dementia. Neurosci Lett. 2005;377(1):37-39.

70. Lehmann DJ, et al. Large meta-analysis establishes the ACE insertion-deletion polymorphism as a marker of Alzheimer's disease. Am J Epidemiol. 2005; 162(4):305-317

71. Narain Y, et al. The ACE gene and Alzheimer's disease susceptibility. J Med Genet. 2000;37(9):695-697.

72. Lendon CL, et al. The angiotensin 1-converting enzyme insertion (I)/deletion (D) polymorphism does not influence the extent of amyloid or tau pathology in patients with sporadic Alzheimer's disease. Neurosci Lett. 2002;328(3):314-318

73. Kehoe PG, Passmore PA. The renin-angiotensin system and antihypertensive drugs in Alzheimer's disease: current standing of the angiotensin hypothesis? I Alzheimers Dis. 2012; 30(suppl 2):S251-S268

74. Jankowsky JL, et al. Co-expression of multiple transgenes in mouse CNS: a comparison of strategies. Biomol Eng. 2001;17(6):157-165.

75. Cole J, et al. Mice lacking endothelial angiotensinconverting enzyme have a normal blood pressure. Circ Res. 2002;90(1):87-92.

76. Langford KG, et al. Transgenic mice demonstrate a testis-specific promoter for angiotensin-converting enzyme. J Biol Chem. 1991; 266(24):15559-15562.

77. Koronyo-Hamaoui $\mathrm{M}$, et al. Identification of amyloid plaques in retinas from Alzheimer's patients and noninvasive in vivo optical imaging of retinal plaques in a mouse model. Neuroimage. 2011; 54(suppl 1):S204-S217.

78. Fuchs $\mathrm{S}$, et al. Role of the $\mathrm{N}$-terminal catalytic domain of angiotensin-converting enzyme investigated by targeted inactivation in mice. J Biol Chem. 2004;279(16):15946-15953

79. Pechnick RN, et al. Developmental exposure to corticosterone: behavioral changes and differential effects on leukemia inhibitory factor (LIF) and corticotropin-releasing hormone $(\mathrm{CRH})$ gene expression in the mouse. Psychopharmacology (Berl). 2006; 185(1):76-83 